Review

\title{
Interaction of chemical contaminants with microplastics: Principles and perspectives
}

\author{
Omowunmi H. Fred-Ahmadu ${ }^{\text {a }}$, Geetika Bhagwat ${ }^{\mathrm{b}}$, Idowu Oluyoye ${ }^{\mathrm{b}}$, Nsikak U. Benson ${ }^{\mathrm{a}, *}$, \\ Olusegun O. Ayejuyo ${ }^{\mathrm{c}}$, Thavamani Palanisami ${ }^{\mathrm{b}, *}$ \\ a Analytical and Environmental Chemistry Unit, Department of Chemistry, Covenant University, Km 10 Idiroko Road, Ota, Nigeria \\ b Global Innovative Centre for Advanced Nanomaterials, School of Engineering, University of Newcastle, Callaghan, NSW 2308, Australia \\ c Department of Chemistry, University of Lagos, Lagos, Nigeria
}

\section{H I G H L I G H T S}

- Plastic additives are multiple stressors of the environment.

- PP-LFERs are more robust and accurate for sorption prediction.

- Sorption is a function of chemical contaminant and polymer properties.

\section{G R A P H I C A L A B S T R A C T}

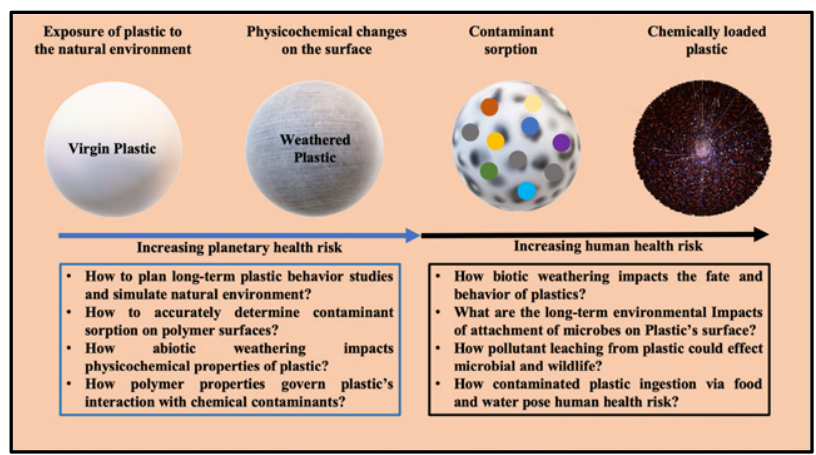

\begin{abstract}
A B S T R A C T
Scientific evidences abound of the occurrence of plastic pollution, from mega- to nano-sized plastics, in virtually all matrixes of the environment. Apart from the direct effects of plastics and microplastics pollution such as entanglement, inflammation of cells and gut blockage due to ingestion, plastics are also able to act as vectors of various chemical contaminants in the aquatic environment. This paper provides a review of the association of plastic additives with environmental microplastics, how the structure and composition of polymers influence sorption capacities and highlights some of the models that have been employed to interpret experimental data from recent sorption studies. The factors that influence the sorption of chemical contaminants such as the degree of crystallinity, surface weathering, and chemical properties of contaminants. and the implications of chemical sorption by plastics for the marine food web and human health are also discussed. It was however observed that most studies relied on pristine or artificially aged plastics rather than field plastic samples for studies on chemical sorption by plastics.
\end{abstract}

(c) 2019 Elsevier B.V. All rights reserved.

\footnotetext{
* Corresponding authors.

E-mail addresses: nsikak.benson@covenantuniversity.edu.ng (N.U. Benson), thava.palanisami@newcastle.edu.au (T. Palanisami).
} 


\section{Contents}

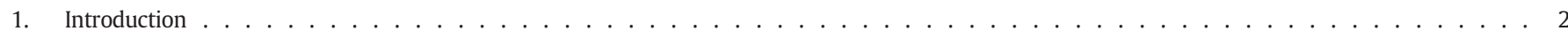

2. Plastic polymers and the role of chemical additives . . . . . . . . . . . . . . . . . . . . . . . . . . . . . . . . . . . . . 2

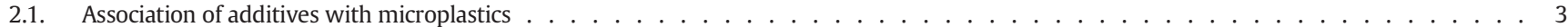

3. Plastic sorption and the role of structure and composition. . . . . . . . . . . . . . . . . . . . . . . . . . . . . . . . . . . . . . 4

4. Factors influencing the sorption of organic chemicals by microplastics . . . . . . . . . . . . . . . . . . . . . . . . . . . . . . . . . . . 4

4.1. Plastic polymer type .. . . . . . . . . . . . . . . . . . . . . . . . . . . . . . . . . . . . 4

4.2. Crystallinity . . . . . . . . . . . . . . . . . . . . . . . . . . . . . . . . . . . . 4

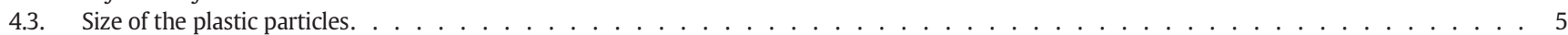

4.4. $\mathrm{pH}$. . . . . . . . . . . . . . . . . . . . . . . . . . . . . . . . . . . . . . . . . 6

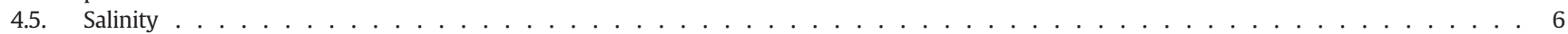

4.6. Ionic strength . . . . . . . . . . . . . . . . . . . . . . . . . . . . . . . . . . . . . . . . . . . . . . 6

4.7. Age and degree of weathering of plastics . . . . . . . . . . . . . . . . . . . . . . . . . . . . . . . . . 6

4.8. Chemical properties of contaminant . . . . . . . . . . . . . . . . . . . . . . . . . . . . . . . . . . . . . . . . . . . . . 6

5. Sorption models for estimating sorption coefficient. . . . . . . . . . . . . . . . . . . . . . . . . . . . . . . . . . . . . . . . . . . 7

5.1. Poly-parameter linear free-energy relationships (PP-LFERs). . . . . . . . . . . . . . . . . . . . . . . . . . . . . . . . . . . . . . 8

5.2. Implications of the sorption constants for the sorption of organic chemicals by plastics . . . . . . . . . . . . . . . . . . . . . . . . 9

6. Fate of plastic-sorbed contaminants in the environment and health risk . . . . . . . . . . . . . . . . . . . . . . . . . . . . . . . . . 9

6.1. Sorption phenomena and its implications to marine food-web . . . . . . . . . . . . . . . . . . . . . . . . . . . . . . . 9

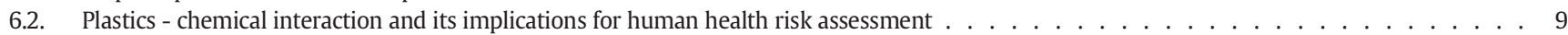

7. Conclusion and future outlook . . . . . . . . . . . . . . . . . . . . . . . . . . . . . . . . . . . . . . . . . . . 10

Acknowledgements . . . . . . . . . . . . . . . . . . . . . . . . . . . . . . . . . . . 10

References. . . . . . . . . . . . . . . . . . . . . . . . . . . . . . . . . . . . . . . . . 10

\section{Introduction}

Plastic pollution and pervasive microplastic fragments have gained recognition globally as emerging environmental problems in freshwater and marine ecosystems. It is estimated that over 8 million tons of plastics are discharged annually into the global oceans as marine litters primarily from land-based activities (Jambeck et al., 2015; Erni-Cassola et al., 2019). The ubiquitous nature of plastics can be linked to their low cost of production, light weight, durability, mechanical strength, water and degradation-resistance, which makes it possible to use them extensively for industrial, commercial, and municipal purposes (Andrady, 2011). The global distribution of plastic debris in marine ecosystems driven by ocean currents and wind poses growing threats to marine fauna, human well-being, the environment, and the economy (Napper \& Thompson, 2019). Furthermore, the severity of ecological impacts as well as risks associated with marine plastic pollution such as entanglements in fishing gear and ropes, and ingestion of floating and sunken plastics by marine and freshwater organisms at all trophic levels have been reported (Murphy et al., 2017; Nelms et al., 2018; Zarfl et al., 2011). According to the Joint Group of Experts on the Scientific Aspects of Marine Environmental Protection, plastic debris are categorized by size into mega- $(>1 \mathrm{~m})$, macro- $(<1 \mathrm{~m})$, meso- $(<2.5 \mathrm{~cm})$, micro- $(<5 \mathrm{~mm})$ and nano- $(<0.1 \mu \mathrm{m})$ plastics (GESAMP, 2015; Thompson, 2016). However, in view of the growing research interest in plastic pollution and the differences in size, origin, colour, polymer type, and shape and structure categorizations posited by experts, a recent systematic gradation framework based on size nomenclature has been proposed and it categorizes marine plastics into: nano(1-1000 nm), micro- (1-1000 $\mu \mathrm{m})$, meso- (1-10 mm), and macroplastics ( $\geq 1 \mathrm{~cm}$ ) (Hartmann et al., 2017; Erni-Cassola et al., 2019). Here, we describe microplastics as plastic particles that are $<5 \mathrm{~mm}$ in length (NOAA, 2018). Microplastics (MPs) have been recognised as prevalent constituents of the marine and coastal environments, and the increasing attention on pollution by MPs are limited in size to those $<5 \mathrm{~mm}$ (Arthur et al., 2009; Zhang et al., 2018b). This is due to the threat they pose largely associated with their composition, size, and their potential to adsorb, release and partition toxic and endocrine disrupting chemical substances in the marine ecosystems (Wang et al., 2015; Pérez-Lobato et al., 2016; Ramirez et al., 2019).
The ability of the MPs to sorb and accumulate both organic and inorganic contaminants is potentially detrimental as the sorbed contaminants can be released into organisms that ingest them and many studies have demonstrated this (Koelmans et al., 2016; Rochman et al., 2013a; Scopetani et al., 2018). Studies have reported the sorption of various contaminants to microplastics, such as polycyclic aromatic hydrocarbons (PAHs), polychlorinated biphenyls (PCBs), dioxin-like chemicals, polybrominated diphenyl ethers (PBDEs), toxic metals, hydrophilic organic compounds (ciprofloxacin), and pharmaceuticals (antibiotics and anti-depressants) (Brennecke et al., 2016; Li et al., 2018; Mato et al., 2001; Rios Mendoza and Jones, 2015; Wang and Wang, 2018a; Wang et al., 2018; Rochman et al., 2013a; Westerdahl et al., 2012). Usually, contaminants in water bodies partition between the aqueous phase and natural and anthropogenic particles that may be present, including microplastics. The determination of particle-bound contaminants and the advancement of the theoretical knowledge of the sorption behaviour of microplastics using laboratory studies is vital for comprehensive risk assessment and management (Wang et al., 2018). Furthermore, an understanding of the structure, the chemistry of sorption/desorption kinetics based on partition coefficients of contaminants improves our knowledge of the role of plastic fragments as vectors of contaminants in the fresh and marine waters. The aim of this paper therefore, is to provide an overview of plastics composition and how their physico-chemical properties influence their ability to sorb chemicals in the aquatic environment. Specifically, we (1) describe how the chemical make-up of plastics provide an insight to their toxic properties (2) highlight the factors that influence the sorption capacities of plastics (3) discuss some common models used in explaining sorption data (4) describe the implications of the sorption process to the marine food web and human health and (5) outline research priorities for improved ecosystem and human health risk assessment.

\section{Plastic polymers and the role of chemical additives}

Plastics are formed by the polymerisation of repeating units called monomers, including other substances such as chemical additives, usually by addition or condensation reactions (Lithner et al., 2011). Additives are chemicals added to polymers to modify their physical and 
mechanical properties in order to make processing easy and derive improved performance. Additives change the structure of polymers and consequently the sorptive capacity is also affected (Endo et al., 2005). Plastic fragments surveyed from the marine environment can be essentially associated with two main types of contaminants (i) chemicals deliberately added during manufacturing process and (ii) chemicals sorbed by plastics from the surrounding media (Endo and Koelmans, 2016). However, due to variability in the characteristics of fieldsurveyed plastic fragments and methodological limitations, it is difficult to distinguish between contaminants (like PBDEs, Bis-phenol A or metals) that are additives and those sorbed from the surrounding water by marine plastics. Although the amount of contaminants that sorb to plastic materials depend on the level of contamination of the surrounding water body, plastic pellets have been shown to accumulate up to $10^{6}$ orders of magnitude organic contaminants (nonylphenols) than in the ambient water column (Mato et al., 2001), suggesting that the excess contamination may have come from leached additives. Since polymers are rarely used in their pure form, most polymers produced for commercial use contain additives. Compounds such as BPA, phthalates and brominated flame retardants are identified as endocrine disruptors which are harmful to both biota and the environment (Hermabessiere et al., 2017). Additives do not usually form covalent bonds with polymers, therefore, they can easily leach from the plastics and enter into the surrounding media (Stringer and Johnston, 2001). There is a varied range of chemicals used to achieve the desired functionality of polymers. Table 1 presents some of the main polymer additives and their functions in plastic products.

\subsection{Association of additives with microplastics}

Studies focusing on the detection of plastic additives in fieldcollected MPs are limited (León et al., 2019; Jang et al., 2017; Net et al., 2015; Rani et al., 2015). However, the recovery of chemical additives from environmental plastic samples is an indication of their persistence and susceptibility to leaching. The release of additives will depend on (i) the pore size of polymer (ii) the size of additive molecule (iii) physico-chemical properties of additives and the surrounding media (Teuten et al., 2009). Luo et al. (2019), investigated the leaching of fluorescent additives from polyurethane (PU) microplastics and reported the release of 3,3'-diaminobenzidine-like substances. The authors concluded that $1.6 \mathrm{~g} / \mathrm{L}$ of microplastics is sufficient to produce concentrations of leachate to exert inhibitory influence on microalgae cell

Table 1

Types of polymer additives and associated applications.

\begin{tabular}{|c|c|c|}
\hline Type of additive & Examples & Purpose \\
\hline $\begin{array}{l}\text { Fillers and } \\
\text { mineral } \\
\text { reinforcements }\end{array}$ & $\begin{array}{l}\mathrm{CaCO}_{3}, \\
\text { mica, talc }\end{array}$ & $\begin{array}{l}\text { To increase bulk, stiffness, } \\
\text { surface hardness. }\end{array}$ \\
\hline Fiber props & $\begin{array}{l}\text { Carbon, aramid, } \\
\text { glass }\end{array}$ & $\begin{array}{l}\text { Improve mechanical } \\
\text { strength }\end{array}$ \\
\hline Colourants & $\begin{array}{l}\text { Pigments, liquid colours, } \\
\text { dyestuff }\end{array}$ & $\begin{array}{l}\text { Add colours, replacement } \\
\text { of heavy metals. }\end{array}$ \\
\hline Heat resistance & $\begin{array}{l}\text { Anti-oxidants - Octylphenol, } \\
\text { nonylphenol, Bis-Phenol A } \\
\text { (BPA) }\end{array}$ & $\begin{array}{l}\text { Delay/avoid oxidation of } \\
\text { polymer when heated. }\end{array}$ \\
\hline UV resistance & $\begin{array}{l}\text { Oxanilides, benzophenones, } \\
\text { benzotriazoles }\end{array}$ & $\begin{array}{l}\text { Slow down/stop oxidation } \\
\text { of plastic under prolonged } \\
\text { sunlight exposure. }\end{array}$ \\
\hline Flame retardants & $\begin{array}{l}\text { Polybrominated } \\
\text { diphenylethers (PBDEs), BPA }\end{array}$ & Prevent ignition of polymer \\
\hline $\begin{array}{l}\text { Anti-statics, } \\
\text { conductive }\end{array}$ & $\begin{array}{l}\text { Glycerol monostearate, Carbon } \\
\text { black, conductive fibers, and } \\
\text { nanomaterials }\end{array}$ & $\begin{array}{l}\text { Enhance electrical } \\
\text { conductivity and avoid } \\
\text { electrostatic discharge. }\end{array}$ \\
\hline $\begin{array}{l}\text { Cross-linking, } \\
\text { coupling }\end{array}$ & Styrene, peroxide, $\mathrm{ZnO}$ & $\begin{array}{l}\text { Improve bonding between } \\
\text { polymers and additives }\end{array}$ \\
\hline Plasticizers & Phthalates & $\begin{array}{l}\text { Improve ease of processing } \\
\text { and flexibility (Ambrogi } \\
\text { et al., 2016) }\end{array}$ \\
\hline
\end{tabular}

photosynthesis. The most common plastic additives include phthalates, bisphenol A (BPA), polybrominated diphenyl ethers (PBDE), nonylphenols (NP), and antioxidants (Hermabessiere et al., 2017), some of which have been detected in microplastics.

Phthalates are phenolic acid esters that possess a wide range of polarity. They are applied to plastics, especially PVC as plasticizers. The use of di(2-ethylexyl) phthalate (DEHP), di-n-butyl phthalate (DnBP) and benzyl butyl phthalate (BBP) in excess of $0.1 \%$ by mass of plastic materials in toys and childcare products was prohibited by the European Parliament Directive 2005/84/EC (Fikarová et al., 2019). DEHP is commonly used in medical devices, cosmetics, personal care products (PCPs), furniture as plasticizer. DEHP and other phthalates have been classified as endocrine disruptors and have shown renal, reproductive, cardio, and neuro-toxicity in organisms (Rowdhwal and Chen, 2018). Phthalates were detected in concentrations up to $6.09 \mathrm{ng} / \mathrm{g}$ in beach microplastics collected from Bohai and Yellow sea of China. DEHP accounted for $64 \%$ of the total concentrations of phthalates; the report suggests that microplastics are a possible source of additives in the marine environment (Zhang et al., 2018b).

Bisphenol $A$ is identified as an endocrine disrupting chemical that has estrogenic effects in aquatic organisms. BPA forms $65 \%$ and $30 \%$ by volume of the monomeric units of polycarbonate (PC) and epoxy resin plastics, respectively (Hermabessiere et al., 2017). BPA usually serves as a plasticizer or antioxidant in polymers like PE, PP, and PVC and like other additives, it may leach from the packaging of food and drinks (Rani et al., 2015). Limited studies are available on the interaction of BPA and its analogues (bisphenol F (BPF), bisphenol S (BPS), bisphenol $\mathrm{B}$ (BPB) and bisphenol AF (BPAF)) with microplastics. A laboratory study showed the adsorption of BPA to PVC microplastics up to a maximum concentration of $0.19 \pm 0.02 \mathrm{mg} / \mathrm{g}$. The maximum adsorption of BPA was attained at a value of $1.5 \mathrm{~g} / \mathrm{L}$ of PVC hence, the value was used throughout the adsorption experiments (Wu et al., 2019).

Poly-brominated flame retardants are a class of 209 congeners of chemicals that function to reduce the rate of combustion and disperse fire by the release of bromine radicals. PBDEs occur as mixtures and are available commercially as pentaBDE, decaBDE and octaBDE. PBDEs are known to have carcinogenic and teratogenic properties as well as pose reproductive toxicity, liver toxicity, and neurotoxicity in mice (USEPA, 2017). The ability of microplastics to act as vectors of PBDE was demonstrated by Chua et al., (2014) in a study where Allorchestes compressa was exposed to PBDE-laden MPs. An uptake of higher brominated BDEs 154 and 153 and lower levels of BDEs 47 and 28 was observed. Rochman et al. (2014), found a positive correlation between the density of plastic debris and the concentration of BDEs 183-209 in the tissues of myctophid fish, which suggests that higher PBDEs that are used as flame retardants may signify plastic contamination in the marine environment. Also, the sorption of PBDEs to PE, PP, PS and PE microplastics was investigated with congeners under different experimental conditions including $\mathrm{pH}$, temperature, salinity and organic matter; congeners BDE 47, 99 and 153 showed dominance in sorption capacity to PS above other polymer types (Xu et al., 2019). Plastic additives (PBDEs, NP, BPA and phthalates) were found present above detection limits in MPs collected from Swiss lakes (Faure et al., 2015).

Nonylphenol is a toxic xenobiotic chemical that is classified as an endocrine disruptor; it is persistent in the environment and is used as antioxidant and plasticizer in some plastics. Nonylphenol surfactants (including Nonylphenol ethoxylates (NPEs)) are also used in household cleaners, lawn care products, laundry detergents, latex paints, spermicides, and cosmetics. (USEPA, 2010). As a result of their uses in household cleaning products, nonylphenol and its surfactants are present in sewage waters, wastewater and soil in micromolar quantities. The ability of nonylphenol to leach from high density-PE, PET and PVC bottles into water was tested by Loyo-Rosales et al., (2004) and concentrations up to 180 and $300 \mathrm{ng} / \mathrm{L}$ were detected in water contained in HDPE and PVC, respectively. In another study, the leaching of nonylphenol surfactants from laboratory plastic ware such as pipette tips and microfuge 
tubes which inhibited mitochondrial complex 1 was reported (Belaiche et al., 2009). Microplastics collected from field survey of Swiss surface waters also showed the detection of nonylphenol (Faure et al., 2015).

Antioxidants are used to inhibit the occurrence of aging in plastics by delaying oxidation. Antioxidant plastic additives have been shown to migrate from different polymer types to oil and food (Reinas et al., 2012). The transfer of the antioxidant plastic additives pentaerythrityl tetrakis(3,5-di-tert-butyl-4-hydroxyphenyl)propionate (Irganox 1010) and tris(2,4-di-tert-butylphenyl)phosphite (Irgafos 168) from polyolefinic packaging (polypropylene, high density polyethylene and ethylene propylene) into five oils, representing lipophilic media was investigated by Marcato et al. (2003). The leaching of the two antioxidants were reported to vary significantly with respect to polyolefin crystallinity, structure and variation in temperature. Nonylphenol and bisphenol A are also antioxidants that have been associated with microplastics. Supporting this reasoning, Marcato et al. (2003) demonstrated the leaching ability of antioxidant additives due to strong affinities to the aforementioned factors.

It is evident from various studies that both pristine plastics and environmentally collected plastics release additives into the surrounding media. Additives in plastics can therefore also be viewed as multiple stressors in the environment due to (i) leaching into the surrounding media posing potential risk (ii) long range transportation (iii) significant contribution to the persistence of plastic materials by reducing their ability to biodegrade.

\section{Plastic sorption and the role of structure and composition}

Sorption is the process of transfer of chemicals from a fluid phase like air or water, to a solid phase. The term "sorption" encompasses both adsorption and absorption. During absorption, the chemical contaminant molecules penetrate and become embedded within the matrix of the solid phase while molecules of the chemical contaminant remain on the interface between the fluid and the solid phases in an adsorption process. Adsorption to the solid surface may include interactions by ionic, van der Waals, steric or covalent bonds while absorption occurs by the partitioning of the sorbate molecules into the sorbent matrix and are held by weak van der Waals forces. This process strongly depends on the hydrophobic properties of the sorbate chemical, the properties of the solid phase and the surface to volume ratio of the solid (Endo and Koelmans, 2016). Surface polarity of microplastics determine how strongly an organic contaminant interacts; hydrophobic organic contaminants (HOCs) preferably adhere to non-polar surfaces (Mato et al., 2002). Usually, the resulting partition coefficient $\left(K_{p w}\right)$ between water and plastic is related to the octanol-water partition ratios $\left(K_{\text {ow }}\right)$ (O'Connor et al., 2016). When concentration of sorbate is low, the partitioning of the organic chemical between the fluid phase and the solid matrix is high, yielding elevated partition ratios, due to stronger forces of interaction at the surface. Therefore, low concentration of sorbate favours adsorption and at high concentration of the sorbate, absorption is more likely due to larger volume (Cornelissen et al., 2005; Hartmann et al., 2017). Sorption can also be considered in terms of chemical (chemisorption) and physical (physisorption) association of sorbate with the sorbent. During chemisorption, the chemicals interact with the solid phase by forming covalent bonds; physisorption on the hand, requires association by non-covalent van der Waals forces. Chemisorption can however be irreversible except when the covalent bonds are broken, making desorption of the chemicals from the solid phase difficult (Endo and Koelmans, 2016). Hence, sorption phenomena leading to desorption of contaminants in the tissue of marine organisms is largely by physisorption and the most significant interactions in the sorption of organic chemicals to plastics are van der Waals forces, hydrogen bonding and cavity formation (Goss and Schwarzenbach, 2003).

Carbon is the most critical element in polymers. It has four valence electrons and achieves stability by sharing four more electrons, forming a wide range of covalent bonds. Most notably, carbon catenates and form strong bonds with itself. The functional groups on a polymer, the presence of unsaturated bonds and hydrophobicity are relevant in the determination of the type(s) and strength of its secondary bonds. For example, PTFE (Teflon) has a structure similar to polyethylene (PE) except that fluorine atoms have replaced all the hydrogen atoms. This confers a nonpolar character on the polymer, without any exposed positive part of the molecule to interact with the negative part of a neighbouring molecule. This effect was corroborated by a study that investigated the sorption of PAHs to PE, PP, PTFE and stainless steel. PTFE and stainless steel were reported to have better recovery rates than PE and PP. It was concluded that loss of analyte is lower when PTFE and stainless steel containers are used in sorption experiments (Krüger et al., 2014). Planar molecules like PAHs typically have higher sorption coefficients than non-planar molecules of similar hydrophobicity (Velzeboer et al., 2014). DLCs are coplanar molecules, hence they have comparatively higher sorption capacities toward plastics (Chen et al., 2019). In humans, toxic effects due to dioxin-like PAHs and PCBs arise from aryl hydrocarbon receptors which bind coplanar molecules with high sorption affinities and transport them into the nucleus (Eichbaum et al., 2014). The character of the pi-electrons in PS is also expected to affect its sorption capacity (Goedecke et al., 2017). The planarity of a molecule affects how close it can move toward the particle surface, thus facilitating adsorption (Velzeboer et al., 2014).

\section{Factors influencing the sorption of organic chemicals by microplastics}

\subsection{Plastic polymer type}

The properties of plastics, such as surface charge, surface area, molecular chain arrangement (Fig. 1), functional groups present, and the acid-base character, influence the sorption of chemicals (Fotopoulou and Karapanagioti, 2012) Additionally, in case of polymer (e.g. nanocomposites or hybrids) that exclusively possess groups that form complexes with the contaminants e.g. metals, the chain structure could prove crucial while understanding the role of planarity on adsorption (Rivas et al., 2018). A measurement of the surface area of plastic types used by Seidensticker et al. (2018), showed PE to be non-porous while PS is mesoporous having a pore size of about 195 Angstrom. This observation resulted in greater sorption of contaminants to PS than PE which is confirmed by a pore-filling mechanism depicted by non-linear sorption isotherms in the study. However, some other studies reported that PE microplastics had higher sorption capacities for hydrophobic organic compounds (HOCs) than polyvinyl chloride (PVC) and polystyrene (PS) particles (Wang and Wang, 2018b; Zuo et al., 2019). The authors attributed their finding to the arrangement of the plastic's molecular chain. The efficiency of sorption also depends on the molecular structure and the composition of microplastics (Wang et al., 2015). A similar occurrence was reported by Lee et al. (2014), where the authors observed that the concentrations of PAHs and PCBs and the partitioning coefficients between the different types of microplastics in seawater followed the order of PS $>$ PE $>$ PP. In another study, PS acted as a sink for PAHs and had 8-200 times order of magnitude sorption for PAHs than PET, PVC, PE and PP (Rochman et al., 2013b). The high sorption capacity of PS has also been related to its amorphous structure. Although sorption capacities vary with polymer types, there appears to be other factors that determine sorption levels.

\subsection{Crystallinity}

Polymers can be categorized into crystalline, semi-crystalline and amorphous phases, depending on the extent of the alignment of their molecular chains. The degree of crystallinity of a polymer is the fraction of the polymer that is crystalline and is expressed as a mass fraction or 
Linear
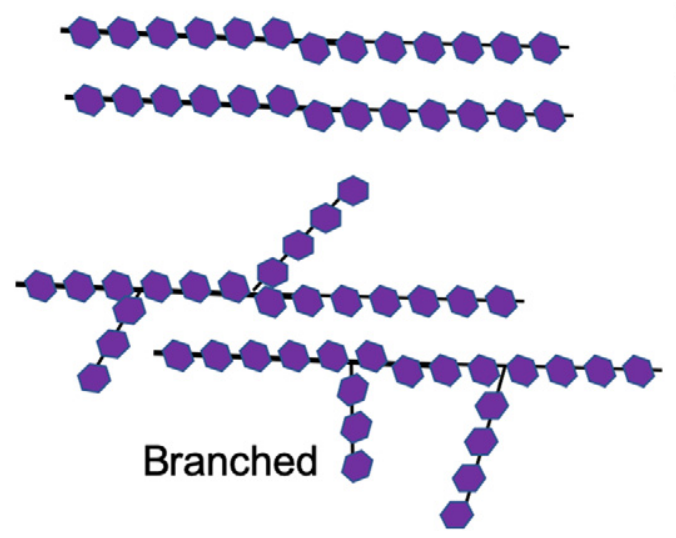

Cross-linked
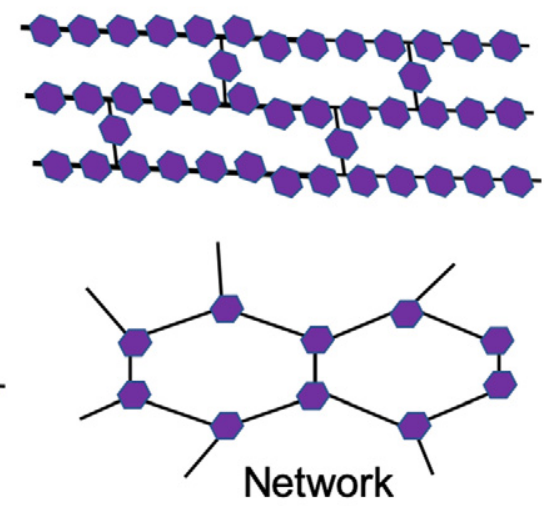

Fig. 1. Polymer chain types.

the volume fraction (Joshi et al., 2017). The degree of crystallinity usually ranges from a few percentage points to about $90 \%$. X-ray diffraction (XRD) is a standard analytical method for the determination of polymer crystallinity. Some examples of semi-crystalline polymers are PE, PP, PTFE, PET and polyacrylonitrile (PAN). The presence of straight chains with regularly spaced side groups promotes crystallization in polymer molecules. Increased crystallinity in pristine plastics was observed to reduce adsorption of ciprofloxacin (G. Liu et al., 2019b). Amorphous polymers, on the other hand, are characterized by chains that are incapable of forming a rigid arrangement. In the solid state, they possess a shortrange order of repeating units. These polymers form an amorphous glassy solid in which the molecular chains are randomly arranged. Poly (methyl methacrylate) and polycarbonate are typical examples of amorphous polymers. Fig. 2 is a pictorial representation of the regions present in a semi-crystalline polymer.

Some of the factors that affect polymer crystallinity include polymer complexity, chain configuration, isomerism, and rate of cooling during solidification. Another important factor to consider is the glass transition property which is only associated with the amorphous domains of a polymer. At low temperature, the amorphous regions of a polymer are in a glassy state so that the molecules only vibrate because they are rigid and frozen. When heat is applied, the polymer will reach a state where it changes from being glassy to a rubbery state. The temperature at which the change occurs is the glass transition temperature ( $\mathrm{Tg}$ ). The glass transition temperatures of commonly detected plastic polymers in the environment is presented in Table 2 . The rubbery segments are

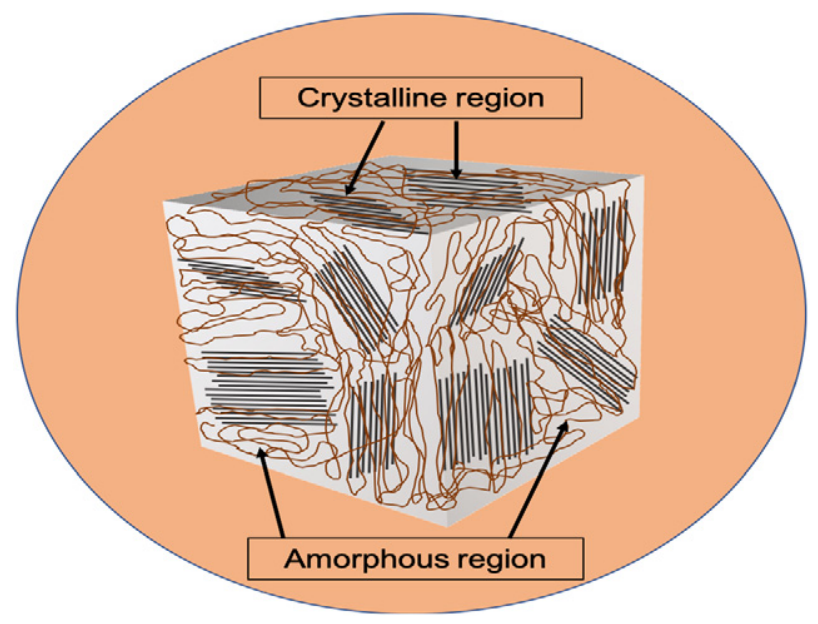

Fig. 2. Structure showing crystalline and amorphous portions of a polymer. highly flexible because molecules have higher freedom to move hence absorption of organic chemicals in this region is enhanced. The sorption isotherm of a rubbery polymer is essentially linear and the absorption process is reversible and non-competitive. Conversely, glassy polymers undergo adsorption, showing competition with any coexisting chemicals and their isotherms are nonlinear (Endo and Koelmans, 2016). The crystalline region within a polymer does not favour the sorption of chemicals due to the high energy that is required to destabilize the strongly ordered polymer chains. However, the amorphous portion of the polymer which has randomly oriented polymeric chains are more available for greater sorption of chemical compounds. This is also corroborated by Guo et al. (2012), where it was reported that the sorption of HOCs was enhanced as the mobile and rubbery domains on the polymers increased. This implies that crystallinity has a profound influence on the sorption capacities of HOCs by plastics.

\subsection{Size of the plastic particles}

From the knowledge of conventional risk assessment in particulates, decreased particle size increases surface area to volume ratio (Endo and Koelmans, 2016) and this is an important parameter in the determination of the extent of risk. Cryo-milling of polypropylene particles to $0.2-0.6 \mathrm{~mm}$ to increase the surface area enhanced the sorption capacity of metformin to the microplastics (Goedecke et al., 2017). During the sorption studies of 3,6 dibromocarbazole and 1,3,6,8 tetrabromocarbazole to polypropylene microplastics, Zhang et al. (2019) observed an increased sorption capacity of the polypropylene particles as particle size decreased between 0.45 and $5 \mathrm{~mm}$. Conversely, Chen et al. (2019), reported that the differences in concentration of

Table 2

Glass transition temperatures ( $\mathrm{Tg}$ ) and densities of selected polymers.

\begin{tabular}{lll}
\hline Polymer & $\operatorname{Tg}\left({ }^{\circ} \mathrm{C}\right)$ & Density $\left(\mathrm{g} / \mathrm{cm}^{3}\right)$ \\
\hline High density polyethylene (HDPE) & -125 & $0.94-0.97$ \\
Low density polyethylene (LDPE) & -130 & $0.91-0.93$ \\
Polypropylene (atactic) & -20 to -5 & $0.85-0.94$ \\
Polyethylene terephthalate (PET) & 70 to 80 & $1.34-1.39$ \\
Polytetrafluoroethylene (PTFE) & 120 to 130 & 2.2 \\
Polyvinyl alcohol & 80 to 90 & 1.19 \\
Polyvinyl chloride (PVC) & 65 to 85 & 1.16 .1 .20 \\
Polypropylene (isotactic) & 100 & 0.92 \\
Polystyrene (PS) & 90 to 110 & $1.04-1.09$ \\
Polyurethane (PU) & 120 to 160 & 1.2 \\
Poly(methyl methacrylate) & 85 to 105 & 1.18 \\
Polyacrylamide & 160 to 170 & 1.11 \\
Polyamide (Nylon 6,6) & 50 to 60 & $1.13-1.15$ \\
\hline
\end{tabular}

Data adapted from Perkinelmer (2019) and Sundt et al. (2014). 
PAHs in small, medium and large plastic particle sizes collected from the open ocean were insignificant. They concluded that pollutant concentrations versus particle size did not occur, which they attributed to the partition sorption mechanisms of PAHs and PCBs. They suggested that the insignificant contribution of particle size effects might become more evident if the particle size used in their study had been smaller. It can then be implied that particle size plays a significant role where sorption of chemical contaminants is concerned. Although, the effects of nano-scale particles are yet to be quantified, the size effect is a matter of concern especially through ambient air.

\section{4. $\mathrm{pH}$}

Freshwater aquatic life requires a $\mathrm{pH}$ range of 6.5-9.0 for existence, and the seawater pH typically ranges between 8.08 and 8.33 (Marion et al., 2011). In aqueous systems, $\mathrm{pH}$ is a critical parameter as it affects the chemical and biological reactions and the equilibrium of such systems. Some studies have investigated the influence of $\mathrm{pH}$ on the strength of sorption of contaminants to plastics. (F. Liu et al., 2019a), found no significant influence of $\mathrm{pH}$ in the sorption of phthalate esters to PE, PS and PVC due to high electrostatic repulsion; as pH increased there was a reduction of hydrophobic interactions between the charged sorbate and sorbent. This was also corroborated by another study where there was a limited effect of variable $\mathrm{pH}$ conditions observed during the sorption experiment of sulfamethoxazole on PE (Xu et al., 2018). This was ascribed to electrostatic repulsion of surface charges. At $\mathrm{pH}$ above 8 , both PE and sulfamethoxazole surfaces had negative charges. However, $\mathrm{pH}$ was found to enhance the adsorption of difenoconazole on PP but not on PA and PS. Liu et al. (2019b), reported differing sorption behaviours of aged and pristine PVC and PS in response to $\mathrm{pH}$ variation. For $\mathrm{PVC}$, sorption efficiency increased with $\mathrm{pH}$ except at $\mathrm{pH}>9$, while for PS, optimum sorption was achieved for aged and pristine PS at pH 8 and 5 , respectively. The sorption of oxytetracycline (an antibiotic compound) on pristine PS was unaffected by changes in $\mathrm{pH}$, but the aged PS had maximum adsorption at $\mathrm{pH} 5$. The authors reported that at $\mathrm{pH} 5$, electrostatic repulsion between the microplastic surface and the oxytetracycline zwitterion was minimal, which is an indication that electrostatic interaction may have a regulatory role in the adsorption process. The role $\mathrm{pH}$ can been explained as follows (i) electrostatic repulsion will increase as solution $\mathrm{pH}$ increases, suppressing electrostatic interaction between different charged sorbate and sorbent; (ii) an increase in pH may promote the dissociation of the hydrophobic neutral sorbate molecules into hydrophilic, negatively charged species, thereby resulting in reduced hydrophobic interaction; (iii) a high pH can increase pi donor ability of sorbate, thus enhancing pi-pi interactions (Liu et al., 2019a).

\subsection{Salinity}

The effect of salinity is dependent by the extent of electrostatic interaction or ion-exchange mechanism of the sorption process. The sorption capacity of virgin microplastics for ciprofloxacin was found to decrease as the degree of salinity increased; salinity significantly lowered adsorption on all the tested microplastics (Liu et al., 2019b). Enhanced salinity had a weak positive effect on the adsorption of difenoconazole on virgin polyamide (PA) and PP but slowed down adsorption in PS (Goedecke et al., 2017). The impact of salinity on the sorption of carbazole on PP was observed to vary in a study by Zhang et al. (2019). The adsorption capacity and rate initially decreased with increasing salinity but later increased and reached a maximum at about $14 \%$ salinity of the solution. Yet, salinity range from $0.05 \%$ to $3.5 \%$ for sulfamethazole sorption showed no significant effects, suggesting that electrostatic interactions had limited influence in the process (Xu et al., 2018). P. Xu et al., (2019) also reported no significant effects of enhanced salinity in the sorption of PBDEs to four microplastics (PE, PP, PA and PS). It appears that sorption by MPs may be contaminant-specific and MPs can sorb contaminants irrespective of the level of salinity of the surrounding media.

\subsection{Ionic strength}

Ionic strength is the total ion concentration in solution. It is a property governing the shielding of charges in solution. Natural water bodies generally contain some level of dissolved salts which in turn translate to their ionic strength. The effect of ionic strength due to the presence of $\mathrm{NaCl}$, and $\mathrm{CaCl}_{2}$ in solution during the sorption of oxytetracycline to PS foams was investigated by Zhang et al. (2018a). It was found that oxytetracycline sorption to both virgin and aged PS decreased as ionic strength increased. Oxytetracycline sorption to the PS microplastics was stronger in the presence of $\mathrm{CaCl}_{2}$ than $\mathrm{NaCl}$, suggesting that sorption of the antibiotic is enhanced by the presence of multivalent cations like $\mathrm{Ca}^{2+}$ through the formation of ternary complexes between the antibiotic, the cations and the surface functional groups (MacKay and Canterbury, 2005). In another study, the adsorption of tylosin on PE, PP, PS and polyvinylchloride (PVC) initially increased in all microplastic types and then decreased as the ionic strength increased (Guo et al., 2018). It was attributed to increased competition for sorption sites as the concentration of $\mathrm{K}^{+}$ions increased. Ionic strength is also a crucial factor for the sorption of metals like lead, copper, uranium and cadmium in the aquatic ecosystem (Guo et al., 2018; Mayer et al., 2014; Wang et al., 2013). Sorption process had been found to decrease by $50 \%$ as the concentration of $\mathrm{Na}^{+}$ions increased from 25 to $300 \mathrm{mg} / \mathrm{L}$ (Xiao et al., 2017). Competition for binding sites between ions in solution and contaminants appears to be the determinant factor for the effects of ionic strength in sorption.

\subsection{Age and degree of weathering of plastics}

Pristine or virgin plastics are those which are manufactured newly and are yet to undergo any abrasion in the environment. Aged or weathered plastics on the other hand, are those that have been exposed to thermal, mechanical, biological, radiative and oxidative pressures which have caused their surfaces to be altered (Albertsson et al., 1987). The alteration of plastic surfaces has been demonstrated to enhance the sorption of metals and organic compounds. Aging enhanced the concentration of some PAH congeners on microplastics (Chen et al., 2019). In a sorption study by Liu et al. (2019), the interaction of ciprofloxacin (a hydrophilic organic compound) on UV-accelerated aged polystyrene and polyvinylchloride showed an elevated sorption capacity than in pristine plastic materials. The authors attributed this to the formation of oxygen-containing functional groups on the plastic surface, and the occurrence of light-induced surface oxidation of the plastics. Peaks characteristic of the hydroxyl group were observed in the aged PS and PVC but were absent in virgin plastics. Results from Hüffer and Hofmann (2016) also suggests that aging reduces hydrophobicity of plastics thereby increasing their sorption capacity for hydrophilic contaminants. Goedecke et al. (2017) studied the interaction of a polar drug (metformin) and a non-polar fungicide (difenoconazole) on virgin MPs of polyamide (PA), polypropylene (PP) and polystyrene (PS). It was found that agitation played a significant role in the level of adsorption of difenoconazole to the plastic particles. Artificial aging in PA and increased surface area in PP enhanced the adsorption of the contaminants. The non-polar compound was found to sorb more to the MPs while the polar compound hardly interacted with the MPs. These evidences suggest that weathered or aged plastics are potentially more likely to be toxic than "unweathered" or pristine plastics of the same polymer type due to higher sorption of contaminants.

\subsection{Chemical properties of contaminant}

Most organic contaminants of environmental concern occur as nonpolar species with limited water solubility making them hydrophobic in 
Table 3

Recent studies of chemical sorption by microplastics and reported results.

\begin{tabular}{|c|c|c|c|c|}
\hline MP type and size & Chemical sorbate & Instrumentation & Results highlight & Reference \\
\hline $\begin{array}{l}\text { Bio-degradable PBAT, PE, PS } \\
(2338 \pm 486,400 \text { and } \\
250 \mu \mathrm{m} \text {, respectively })\end{array}$ & $\begin{array}{l}\text { Phenanthrene } \\
\text { (Phe) }\end{array}$ & $\begin{array}{l}\text { Thermo gravimetric analyzer } \\
\text { (TGA), Fourier transform } \\
\text { infra-red (FTIR), XRD, } \\
\text { DSC, pyrolysis GC-MS. }\end{array}$ & $\begin{array}{l}\text { Bio-degradable PBAT sorbed } 3 \text { times } \\
\text { and } 40 \text { times more Phe than PE and PS. }\end{array}$ & $\begin{array}{l}\text { Zuo et al. } \\
\text { (2019) }\end{array}$ \\
\hline $\begin{array}{l}\text { UV-accelerated PS and PVC } \\
\quad(75 \mu \mathrm{m})\end{array}$ & $\begin{array}{l}\text { Ciprofloxacin } \\
\text { (CIP) }\end{array}$ & $\begin{array}{l}\text { XRD, FTIR, UV-VIS } \\
\text { spectrophotometer }\end{array}$ & $\begin{array}{l}\text { UV-induced aging increased sorption } \\
\text { of CIP by } 123.3 \% \text { and } 20.4 \% \text { to PS and } \\
\text { PVC, respectively. }\end{array}$ & $\begin{array}{l}\text { Liu et al. } \\
\text { (2019) }\end{array}$ \\
\hline $\begin{array}{l}\text { Pristine and aged PS } \\
\quad(125-250 \mu \mathrm{m})\end{array}$ & $\begin{array}{l}\text { Organic compounds } \\
\text { (not named) }\end{array}$ & $\begin{array}{l}\text { Scanning electron microscope } \\
\text { (SEM), ATR-FTIR, GC-MS }\end{array}$ & $\begin{array}{l}\text { UV-induced aging decreased sorption of } \\
\text { sorbate } \\
\text { to PS MPs. }\end{array}$ & $\begin{array}{l}\text { Hüffer et al. } \\
\text { (2018) }\end{array}$ \\
\hline $\begin{array}{l}\text { Beached and virgin PS } \\
\quad(0.45-1 \mathrm{~mm})\end{array}$ & Oxytetracycline & $\begin{array}{l}\text { ATR-FTIR, Elemental analyzer, } \\
\text { potentiometric titration, HPLC }\end{array}$ & $\begin{array}{l}\text { Adsorption of sorbate on beached MPs } \\
\text { was } 2 \\
\text { times that of virgin MPs. }\end{array}$ & $\begin{array}{l}\text { Zhang et al. } \\
\text { (2018a) }\end{array}$ \\
\hline $\begin{array}{l}\text { HDPE, PS and PVC } \\
\qquad(100-150 \mu \mathrm{m})\end{array}$ & Pyrene & SEM, MP surface analyzer & $\begin{array}{l}\text { Affinity for pyrene followed the order } \\
\text { PE }>\text { PS > PVC }\end{array}$ & $\begin{array}{l}\text { Wang and } \\
\text { Wang } \\
(2018 \mathrm{a})\end{array}$ \\
\hline $\mathrm{PE}(45-48 \mu \mathrm{m})$ & $\begin{array}{l}\text { Sulfamethoxazole (SMX), } \\
\text { propranolol (PRP), sertraline (SER) }\end{array}$ & SEM, UPLC/MS/MS & $\begin{array}{l}\text { Sorption order on PE was } \\
\text { SER }>\text { PRP }>\text { SMX }\end{array}$ & $\begin{array}{l}\text { Razanajatovo } \\
\text { et al. (2018) }\end{array}$ \\
\hline $\begin{array}{l}\text { PE, PS, PP, PA and PVC } \\
\quad(75-180 \mu \mathrm{m})\end{array}$ & $\begin{array}{l}\text { Sulfadiazine (SDZ), amoxicillin (AMX), } \\
\text { tetracycline (TC), ciprofloxacin (CIP), } \\
\text { trimethoprim (TMP) }\end{array}$ & SEM, XRD, HPLC & $\begin{array}{l}\text { On PS, PE, PP and PVC, sorption decreased } \\
\text { in } \\
\text { order CIP }>\text { AMX }>\text { TMP }>\text { SDZ }>\text { TC. } \\
\text { PA had high affinity for AMX, TC and } \\
\text { CIP in freshwater. }\end{array}$ & $\begin{array}{l}\text { Li et al. } \\
(2018)\end{array}$ \\
\hline $\mathrm{PE}(150 \mu \mathrm{m})$ & Sulfamethoxazole & $\begin{array}{l}\text { SEM, electro kinetic } \\
\text { analyzer, HPLC }\end{array}$ & $\begin{array}{l}\text { Negligible effects of } \mathrm{pH} \text {, salinity and } \\
\text { dissolved organic matter (DOM) on } \\
\text { sorption capacity, }\end{array}$ & $\begin{array}{l}\text { Xu et al. } \\
(2018)\end{array}$ \\
\hline PE, PP, PS and PVC (<200 mesh) & Tylosin & $\begin{array}{l}\text { SEM, Brunner-Emmet-Teller } \\
\text { (BET), FTIR, Zeta potential }\end{array}$ & $\begin{array}{l}\text { Sorption of tylosin increased in the order } \\
\mathrm{PE}<\mathrm{PP}<\mathrm{PS}<\mathrm{PVC}\end{array}$ & $\begin{array}{l}\text { Guo et al. } \\
\text { (2018) }\end{array}$ \\
\hline PE, PS and PVC (100-150 $\mu \mathrm{m})$ & Phenanthrene and pyrene & BET, SEM. GC-MS & $\begin{array}{l}\text { MPs affinity for Phe followed the order } \\
\text { PE > PS > PVC but the sorption level } \\
\text { decreased in the presence of pyrene. }\end{array}$ & $\begin{array}{l}\text { Wang and } \\
\text { Wang } \\
(2018 b)\end{array}$ \\
\hline Virgin PA, PP and PS (3-5 mm) & Metformin and Difenoconazole & $\begin{array}{l}\text { Dynamic Scanning } \\
\text { Calorimetry (DSC), Gel } \\
\text { Permeation Chromatography } \\
\text { (GPC), FTIR, LC-DAD, GC-MS }\end{array}$ & $\begin{array}{l}\text { Difenoconazole adsorption followed } \\
\text { the order PS }>\text { PP }>\text { PA while no } \\
\text { adsorption occurred for metformin on all } \\
\text { MP pellets }\end{array}$ & $\begin{array}{l}\text { Goedecke } \\
\text { et al. (2017) }\end{array}$ \\
\hline $\begin{array}{l}\mathrm{PP}(0.18-0.425,0.425-0.85 \\
\quad 0.85-2,2-5 \mathrm{~mm})\end{array}$ & $\begin{array}{l}3,3^{\prime}, 4,4^{\prime} \text { tetrachloro biphenyl } \\
\text { (PCB 77) }\end{array}$ & GC-ECD & $\begin{array}{l}\text { Particle size, temperature and solution } \\
\text { environment had significant impact on } \\
\text { sorption behaviour. }\end{array}$ & $\begin{array}{l}\text { Zhan et al. } \\
\text { (2016) }\end{array}$ \\
\hline PE, PA, PS and PVC & $\begin{array}{l}\text { n-hexane, cyclohexane, benzene, } \\
\text { toluene, chlorobenzene, ethyl } \\
\text { benzene and naphthalene }\end{array}$ & $\begin{array}{l}\text { Particle size and shape analyzer, } \\
\text { GC-MS }\end{array}$ & $\begin{array}{l}\text { Sorption increased in the order } \\
\mathrm{PA}<\mathrm{PE}<\mathrm{PVC}<\mathrm{PS}\end{array}$ & $\begin{array}{l}\text { Hüffer and } \\
\text { Hofmann } \\
(2016)\end{array}$ \\
\hline
\end{tabular}

nature. The sorption of HOCs by microplastics is highly dependent on the properties of the specific contaminant and the polymer (Bakir et al., 2014). Studies demonstrating the sorption of different contaminants on the same type of MP have shown different sorption behaviour attributed to differences in contaminant octanol-water coefficient $\left(\mathrm{K}_{o w}\right)$ values (Guo et al., 2012). Hydrophobic interaction mechanism was found to dominate in the sorption of two perfluorochemicals to PE, PS and PVC microplastics (Wang et al., 2015). The ability to partition between water and an organic phase measured by the plastic-water coefficient $\left(\mathrm{K}_{p w}\right)$, octanol-water coefficient $\left(\mathrm{K}_{o w}\right)$ and aqueous solubility $\left(\mathrm{S}_{w}\right)$ are some of the hydrophobic factors considered in the prediction of the sorption behaviour of organic contaminants.

In recent years, researchers have investigated the sorption behaviour and mechanisms of different chemical compounds including persistent organic pollutants, pharmaceuticals, antibiotics, hydrophilic compounds, aliphatic and aromatic compounds. Table 3 shows some of such studies:

\section{Sorption models for estimating sorption coefficient}

Many models exist for the study of the adsorption and desorption mechanisms of contaminants sorbed to microplastics. The most commonly used adsorption kinetic models include the first-order adsorption kinetics model (Skrip et al., 2013) and pseudo-second-order adsorption kinetics model (Miyake et al., 2013). Others are intraparticle diffusion and film diffusion models (Zhang et al., 2018a). Sorption equilibrium is established when the concentration of sorbate in the bulk solution is in dynamic balance with that of the interface. The equilibrium data are usually fitted into Henry's isotherm (one parameter model), linear or non-linear Langmuir and Freundlich isotherms which are two-parameter models (Ayawei et al., 2017). Adsorption isotherms are used to predict the amount of sorbate that can sorb to a solid surface while kinetics models are used to estimate the efficiency of sorption. The isotherms are a graphical representation of the association between the sorbate concentration per unit weight of the sorbent and the remnant amount of sorbate at equilibrium (Desta, 2013). Table 4 presents some common models used to describe the sorption process. Adsorption kinetics typically involves four independent consecutive or parallel steps (a) bulk transport, (b) external mass transfer (film transport), (c) intra-particle diffusion and (d) chemisorption (Ho et al., 2000). A representation of the sorption process is depicted in Fig. 3.

The Langmuir model is typically designed for gas-solid adsorption. It balances relative adsorption and desorption by accounting for adsorbent surface coverage such that adsorption is directly proportional to the open adsorbent surface as desorption is to the covered adsorbent surface (Ayawei et al., 2017). The model is based on the following basic assumptions:

a) A dynamic equilibrium exists between adsorbed ions or molecules and the free ions or molecules.

b) The whole surface of the adsorbent is uniform.

c) The molecules that have adsorbed have no form of interaction with each other.

d) The mechanism is the same for to all adsorptions. 
Table 4

Common kinetics and isotherm models used in sorption/desorption studies.

\begin{tabular}{|c|c|c|}
\hline Type of model & Equation & References \\
\hline \multicolumn{3}{|l|}{ Kinetic models } \\
\hline Pseudo first order & $\begin{array}{l}\log \left(q_{m}-q_{t}\right)=\log q_{m} \\
-k_{1} / 2.303 t\end{array}$ & $\begin{array}{l}\text { Ho et al. } \\
\text { (2000) }\end{array}$ \\
\hline Pseudo second order & $1 / \mathrm{q}_{\mathrm{t}}=1 / \mathrm{k}_{2} \mathrm{q}_{\mathrm{m}}^{2}+1 / \mathrm{q}_{\mathrm{m}} \mathrm{t}$ & $\begin{array}{l}\text { Ho et al. } \\
(2000)\end{array}$ \\
\hline Intra-particle diffusion & $\mathrm{q}_{\mathrm{t}}=\mathrm{K}_{\mathrm{id}} \times \mathrm{t}^{1 / 2}+\mathrm{C}_{\mathrm{i}}$ & $\begin{array}{l}\text { Weber \& } \\
\text { Morris } \\
(1962)\end{array}$ \\
\hline Film diffusion & $\mathrm{B}_{\mathrm{t}}=-\ln \left(1-\mathrm{q}_{\mathrm{t}} / \mathrm{q}_{\mathrm{e}}\right)-0.4977$ & $\begin{array}{l}\text { Martins } \\
\text { et al. } \\
(2015)\end{array}$ \\
\hline $\begin{array}{l}\text { Intra-particle diffusion } \\
\text { (desorption) }\end{array}$ & $\begin{array}{l}\text { fdesorbed }(\mathrm{t})=1-\mathrm{M}_{\mathrm{t}} / \mathrm{M}_{\mathrm{o}}=1 \\
-6 / \pi^{2} \sum 1 / \mathrm{n}^{2} \exp \left(-\mathrm{n}^{2} \pi^{2} \mathrm{tD}_{\mathrm{P}} / \mathrm{r}^{2}\right)\end{array}$ & $\begin{array}{l}\text { Endo et al. } \\
\text { (2013) }\end{array}$ \\
\hline $\begin{array}{l}\text { Aqueous boundary layer } \\
\text { diffusion (desorption) }\end{array}$ & $\begin{array}{l}\text { fdesorbed }(t)=1-M_{t} / M_{o}=1 \exp \\
\left(D_{w} S A_{P} t / \delta V_{P} K_{P / w}\right)=1-\exp \\
\left(-3 D_{w} t / r \delta K_{P / w}\right)\end{array}$ & $\begin{array}{l}\text { Endo et al. } \\
\text { (2013) }\end{array}$ \\
\hline \multicolumn{3}{|l|}{ Isotherm models } \\
\hline $\begin{array}{l}\text { Henry's isotherm } \\
\text { (linear) }\end{array}$ & $\mathrm{q}_{\mathrm{e}}=\mathrm{K}_{\mathrm{d}} \times \mathrm{C}_{\mathrm{e}}$ & $\begin{array}{l}\text { Ayawei } \\
\text { et al. } \\
(2017)\end{array}$ \\
\hline Langmuir (nonlinear) & $\mathrm{qe}=\mathrm{Q}_{\max } \times \mathrm{K}_{\mathrm{L}} \times \mathrm{C}_{\mathrm{e}} / 1+\mathrm{K}_{\mathrm{L}} \times \mathrm{C}_{\mathrm{e}}$ & $\begin{array}{l}\text { Teuten } \\
\text { et al. } \\
(2007)\end{array}$ \\
\hline Langmuir (linear) & $\begin{array}{l}\mathrm{Ce} / \mathrm{qe}=1 / \mathrm{qmK}_{\mathrm{L}}+\mathrm{Ce} / \mathrm{qm} \\
\mathrm{qe} / \mathrm{Ce}=\mathrm{K}_{\mathrm{L}} \mathrm{qm}-\mathrm{K}_{\mathrm{L}} \mathrm{qe} \\
1 / \mathrm{qe}=\left[1 / \mathrm{qmK}_{\mathrm{L}}\right] 1 / \mathrm{Ce}+1 / \mathrm{qm}\end{array}$ & $\begin{array}{l}\text { Ayawei } \\
\text { et al. } \\
\text { (2017) }\end{array}$ \\
\hline Freundlich (nonlinear) & $\mathrm{q}_{\mathrm{e}}=\mathrm{K}_{\mathrm{f}} \times \mathrm{C}_{\mathrm{e}}^{1 / \mathrm{n}}$ & $\begin{array}{l}\text { Teuten } \\
\text { et al. } \\
\text { (2007) }\end{array}$ \\
\hline Freundlich (linear) & $\log q_{e}=\log K_{f}+1 / n \log C_{e}$ & $\begin{array}{l}\text { Teuten } \\
\text { et al. } \\
\text { (2007) }\end{array}$ \\
\hline
\end{tabular}

e) At maximum adsorption, molecules only deposit on the adsorbent surface and not on each other (monolayer adsorption) (vlab. amrita.edu, 2011).

Where $\mathrm{q}_{\mathrm{m}}$ and $\mathrm{q}_{\mathrm{e}}$ are the amount of adsorbate at equilibrium or adsorption capacity $(\mathrm{mg} / \mathrm{g})$; qt is the adsorbed amount at time t; Kid and $\mathrm{Ci}$ are intra-particle diffusion constants, $\mathrm{k} 1$ and $\mathrm{k} 2$ are the rate constants; Bt is Boyd constant; Kd is partition coefficient between the sorbent and the solution at equilibrium; Ce is the sorbate concentration at equilibrium; Qmax is the maximum adsorption capacity; $\mathrm{K}_{\mathrm{L}}$ is Langmuir constant $(\mathrm{mg} / \mathrm{g}) ; \mathrm{Kf}$ is sorption affinity coefficient $(\mathrm{L} / \mathrm{mg})$ and $1 /$ $\mathrm{n}$ is adsorption intensity (Freundlich constants); fsorbed is cummulative fraction of desorbed contaminant between time 0 and $t$, Mo and Mt. are initial mass and mass of sorbate remaining at time t, respectively; Dp is diffusion coefficient in plastic; $r$ is radius of plastic, Dw

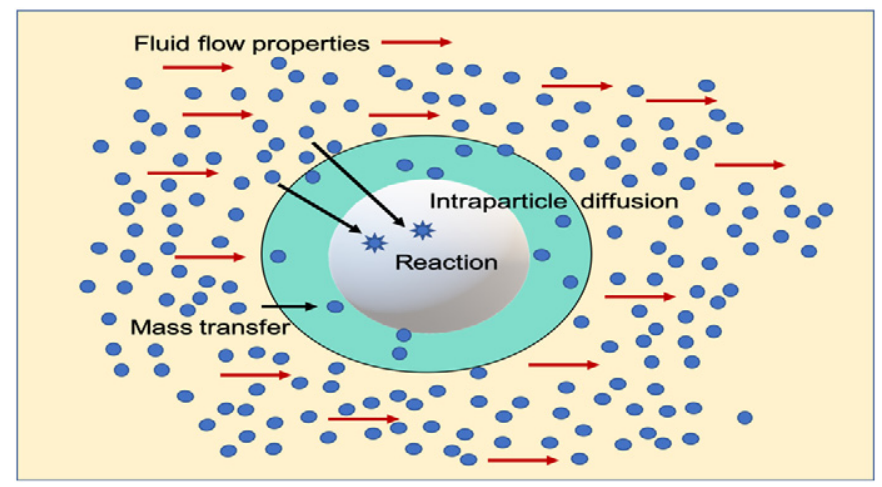

Fig. 3. Sorption of sorbate on a solid surface. is diffusion coefficient in water, Sap is surface area of plastic; $\delta$ is the thickness of aqueous boundary layer; $\mathrm{Vp}$ is volume of the plastic; $\mathrm{Kp} /$ $\mathrm{W}$ is partition coefficient between water and plastic.

The Freundlich model is used to describe both linear and nonlinear sorption. In recent sorption experiments, both PE and nylon fibers showed linear isotherms toward phenanthrene thus indicating their strong affinity and sorption capacity. However, the evaluated Freundlich $\log \mathrm{K}_{\mathrm{f}}$ parameter revealed that PE fibers had 1-2 orders of magnitude sorption capacity than the nylon fibers (Wang et al., 2018). Zuo et al. (2019), fitted sorption data for kinetics study into pseudo second-order model as a result of the success of the model from similar studies. The authors found the Freundlich linear model more appropriate to explain the sorption of phenanthrene on biodegradable plastics of PE and poly (butylene adipate co-terephthalate) (PBAT). Generally, adsorption studies begin with a series of batch experiments where sampled data are analyzed over equal time intervals. Experiments are usually conducted at room temperature except where the effects of variable temperature on sorption is being considered. A high correlation coefficient $\left(R^{2}\right)$ value and the closeness of the experimental and theoretical values of the adsorption capacities of the sorbate $\left(\mathrm{q}_{\mathrm{e}}\right)$ are essential. In a series of experiments conducted to establish model adsorption isotherms, three isotherm models namely Freundlich, Langmuir and Dubinin-Radushkevich were tested to determine the correlation of four sets of data. The differences in the $\mathrm{R}^{2}$ values and standard error values were used as parameters to determine the best model for the data. Langmuir linear model was found to have the most significant value of $\mathrm{R}^{2}$ and the lowest of standard error hence it was considered the best model for the dataset (Chen, 2015). In another sorption study, the $\mathrm{R}^{2}$ value for pristine PVC and PS were found to be higher when fitted into a pseudo first order than the pseudo second-order model while the data for the aged version of the same plastics fitted into a pseudo second-order model (Liu et al., 2019b). The decision of fitting experimental data into a kinetic or isotherm model appears to be based on their success with previous studies or a trial and error process. The one-parameter linear free energy relationships (OP-LFERs) (i.e. $K_{p w}, K_{o w}, S_{w}$ ) and two-parameter models are limited in that they can only predict variability within a single class of compounds (Endo and Koelmans, 2016) and are inadequate for contaminants with tendency for strong hydrogen bonding and specific interactions with the organic phase (Nguyen et al., 2005). Hence, models known as polyparameter linear free-energy relationships (PP-LFERs) which accounts for various intermolecular interactions to $\log K_{p w}$ have been used to describe sorption more accurately.

\subsection{Poly-parameter linear free-energy relationships (PP-LFERS)}

PP-LFERs are reliable models that can be used to predict the partition coefficients for several thousands of environmental phases with high accuracy. They can be applied to almost any neutral compound irrespective of chemical class with prediction errors $<0.3 \log$ units and accounts for contributions toward free energy change from wide range of molecular interactions with both water and bulk organic phases (Stenzel et al., 2013). For example, the Abraham Linear Solvation Energy Relationships (LSERs) for $K_{p w}$ is given as.

$\log K_{p w}=\mathrm{c}+\mathrm{eE}+\mathrm{sS}+\mathrm{aA}+\mathrm{bB}+\mathrm{vV}$

where $\mathrm{E}=$ excess molar fraction.S = solute dipolarity/polarizability. $\mathrm{A}=$ solute $\mathrm{H}$-bond donor property (acidity). $\mathrm{B}=$ solute $\mathrm{H}$-bond acceptor property (basicity). $V=$ molar volume.

E, S, A, B and V are the solute descriptors while c, e, s, a, b and v are regression coefficients. The solute descriptors describe the ability of the contaminant to undergo molecular interactions and the regression coefficients are indicative of the differences in particular interaction characteristics between plastic and water (Endo and Koelmans, 2016). Few recent studies on sorption of HOCs to plastics have applied the 
Abraham LSERs (Hüffer et al., 2018; Uber et al., 2019). In the study by Uber et al. (2019), the sorption properties of HDPE for non-ionic organic compounds was investigated using the linear, Freundlich and PP-LFER models for interpretation of data. At aqueous concentrations below $10^{-2} \mu \mathrm{g} / \mathrm{L}$, linear isotherm resulted in a $\mathrm{R}^{2}>0.5(p<0.5)$ while the nonlinear Freundlich isotherm yielded $\mathrm{R}^{2}>0.75(p<0.05)$ suggesting that pore-filling adsorption is more relevant in the sorption process and that the Freundlich nonlinear isotherm gives a better fit than the linear isotherm. However, using the PP-LFER model, $\mathrm{R}^{2}>0.84$ and root mean square error (RMSE) of 0.27 was obtained compared to RMSE of 0.52 for Freundlich isotherm indicating the robustness of the PP-LFER model for sorption by HDPE. There are also other PP-LFERs commercial software that do not require experimental descriptors and fitting coefficients; they rely solely on the molecular structures of polymer and the contaminants as inputs. Examples are COSMOtherm and SPARC; their prediction accuracy averagely lies within $1.0 \mathrm{log}$ unit. Their application for polymer sorption is however limited (Endo and Koelmans, 2016). The descriptors for many compounds are available but for most environmentally relevant plastic types, regression coefficients are still lacking.

\subsection{Implications of the sorption constants for the sorption of organic} chemicals by plastics

The respective sorption coefficients, $\mathrm{K}_{\mathrm{L}}$ and $\mathrm{K}_{\mathrm{f}}$ in the Langmuir and Freundlich isotherms describe the partition of the organic sorbate between the existing aqueous solution and the plastic particles. The values of the sorption coefficients depend largely on the intermolecular interaction of the organic chemical in/on plastic and the surrounding water. Generally, hydrophobic organic chemicals (HOCs) exhibit favourable energy for interaction with plastic than the water phase; hence the chemical is more enriched in the plastic-water phase at equilibrium. (Endo and Koelmans, 2016). The parameter, $1 / \mathrm{n}$ in the Freundlich model is the exponent of non-linearity. It is associated with compounds of very low hydrophobicity. In most cases, the value of $1 /$ $\mathrm{n}$ ranges between 0.7 and 1 showing that when the sorbate concentration increases, its relative adsorption decreases. This is also an indication that no adsorption site is available on the adsorbent for further sorption, suggesting a saturation and less adsorption occurs. $1 / \mathrm{n}$ values are rarely $>1$ except in compounds containing polar functional groups at low concentrations. However, $1 / \mathrm{n}$ values of $<0.7$ are indicative of highly curved, nonlinear isotherms. The $\mathrm{R}^{2}$ value is an expression of the reproducibility of the data used to generate the Freundlich and Langmuir adsorption coefficients, $\mathrm{K}_{\mathrm{f}}$ and $\mathrm{K}_{\mathrm{L}}$, respectively. The closer the value is to 1, the more reproducible the data (European Centre for Ecotoxicology and Toxicology of Chemicals, 2013).

\section{Fate of plastic-sorbed contaminants in the environment and health risk}

Common environmental organic contaminants such as PAHs show high partition coefficients with respect to plastics, indicating their strong affinities for plastic polymers. Partition coefficients of phenantrene to PE, PP and PVC were reported to be $38,100 \pm 5600$, $2190 \pm 170$ and $1650 \pm 200$, respectively (Teuten et al., 2007). Some of the frequently detected environmental plastics are less dense than seawater (density $1.02 \mathrm{~g} / \mathrm{cm}^{3}$ ) hence they float and are able to sorb contaminants in the surface microlayer (SML) of water bodies (refer to Table 2). The floating contaminant-laden plastics are accessible to seabirds and marine organisms in the epipelagic zone for ingestion. Conversely, polymers like PVC, PS and PU and plastics with fouled surfaces, including the effects of additives have higher density than seawater or freshwater. Therefore, contaminant-sorbed plastics of this nature sink to the bottom of the water and are available to benthic organisms for ingestion (Teuten et al., 2007). The sorbed chemical contaminants have capacity to desorb from plastics into organisms (Bakir et al., 2014; Rochman, 2015) and biomagnify from lower trophic organisms to fish (Kelly et al., 2007). The bioaccumulation of PCBs associated with plastics was demonstrated in lugworms, which resulted in weight loss and reduction in their feeding activity (Besseling et al., 2013).

\subsection{Sorption phenomena and its implications to marine food-web}

One of the most crucial problems with marine microplastics is their ability to act as vectors of harmful chemical contaminants. They are regarded as multiple stressors because they have the potential to impact organisms both physically and chemically (Rochman, 2013). Microplastics ingestion has been reported in organisms at virtually every trophic level, including zooplanktons, mussels and lugworms, shell fish, cetaceans, fish, seabirds and large sea mammals (Cho et al., 2019; Sun et al., 2018; Van Cauwenberghe et al., 2015; Neves et al., 2015). In addition, digestive fluids promote the leaching of sorbed contaminants on microplastic particles (Voparil and Mayer, 2000). The longer the ingested MPs stay in the guts of the organism, the higher the likelihood that the contaminants will translocate into the body tissue (Chua et al., 2014). In another study, Bakir et al., (2014) showed that the presence of organic matter (gut surfactants) significantly enhanced the desorption of organic pollutants from microplastics. Polybrominated diphenyl ethers (PBDEs) were loaded into MPs isolated from commercially sold cleansing soap and exposed to Allorchestes compressa (marine amphiphods) for $72 \mathrm{~h}$. Thereafter, gut clearance was allowed for $48 \mathrm{~h}$ in fresh seawater before oven-drying, homogenization, extraction and analysis. It was found that PBDEs sorbed on microplastics were assimilated into the tissue of the marine amphiphods (Chua et al., 2014). A study established an artificial food chain between Artemia nauplii and Dania rerio (zebrafish) and monitored the uptake and transfer of two sets of virgin microplastics (1-20 $\mu \mathrm{m})$. The first set was loaded with benzo(a)pyrene (BaP) while the other set was without BaP. Although no physical harm was recorded with MPs not loaded with BaP, some of the particles were retained in the guts of the zebrafish. On the other hand, the transfer of BaP by the loaded microplastic particles to zebrafish from the ingestion of Artemia nauplii was confirmed by fluorescence analysis. The study suggests that pollutant-loaded microplastics in invertebrate organisms ingested as food can leach in the intestine of vertebrate organisms and translocate to the stomach walls and the liver (Batel et al., 2016). These studies provide useful information that indicate the complex interaction of sorbed contaminants with biological systems.

\subsection{Plastics - chemical interaction and its implications for human health risk assessment}

Humans are exposed to microplastics uptake via the consumption of sea foods, drinking water, plastic-packaged drinks and inhalation (Digka et al., 2018; Eerkes-Medrano et al., 2015; Peixoto et al., 2019), including fishes from aquaculture (Cheung et al., 2018). There have also been reports of microplastics detection in food products like salt (Yang et al., 2015), sugar and honey (Liebezeit and Liebezeit, 2013), beer (Liebezeit and Liebezeit, 2014) and canned foods (Karami et al., 2018). Although scientific evidences abound on the occurrence of microplastics in foods consumed by humans and the capacity of microplastics to sorb harmful contaminants, no information is available yet about the fate of microplastics in the human body on the basis of microplastics ingestion (Rist et al., 2018). However, the bioaccumulation of MPs and sorbed POPs from lower nutrient levels may eventually impact human health (Miranda and de Carvalho-Souza, 2016). The risk of microplastics exposure to humans increases when sea organisms are consumed whole compared to when the digestive tracts are removed before consumption (Carbery et al., 2018). Particle toxicity is a viable perspective to determine potential toxic effects in humans. Drawing from other research fields involved in human toxicity studies due to particulate matter like air pollution, fiber technology and 
nanotoxicology, it can be concluded that smaller particles, in the nanometer range may be able to cross cell membranes into body fluids resulting in cell damage, inflammation, and oxidative stress (Rist et al., 2018; Vethaak and Leslie, 2016). Further investigation and synchronization of collected environmental data will aid the performance of risk assessment of human health risk due to exposure to contaminated food. As microplastic pollution is increasing in the environment, it is expedient that research efforts be intensified on risk prediction, assessment and management concerning human health.

\section{Conclusion and future outlook}

The ability of plastics of various sizes to adsorb organic and inorganic contaminants in the environment is not in doubt. However, an understanding of the fate and transport mechanisms is required for effective toxicity studies, risk management and the prediction associated health effects. The sorption and transfer of toxic contaminants ingested with microplastics may likely impact the health of humans in the long term. Therefore, for effective and comprehensive risk prediction and assessment of the impact of plastic and microplastics pollution, future research should focus on (a) developing regression descriptors for frequently detected environmental plastics is required for accurate estimation of sorption coefficients (b) the sorption and desorption of chemical additives on microplastics (c) sorption studies of field-collected microplastics in the long term.

\section{Declaration of competing interest}

The authors declare they have no actual or potential competing financial interests.

\section{Acknowledgements}

The authors wish to acknowledge financial support from the Association of Commonwealth Universities Blue Charter Fellowships, United Kingdom and Covenant University, Ota Nigeria.

\section{References}

Albertsson, A.C., Andersson, S.O., Karlsson, S., 1987. The mechanism of biodegradation of polyethylene. Polym. Degrad. Stab. 18, 73-87. https://doi.org/10.1016/0141-3910 (87) $90084-X$.

Ambrogi, V., Carfagna, C., Cerruti, P., Marturano, V., 2016. Additives in polymers. Modification of Polymer Properties, pp. 87-108. https://doi.org/10.1016/B978-0-323-443531.00004-X.

Andrady, A.L., 2011. Microplastics in the marine environment. Mar. Pollut. Bull. 62, 1596-1605. https://doi.org/10.1016/j.marpolbul.2011.05.030.

Arthur, C., Baker, J., Bamford, H., 2009. Proceedings of the International Research Workshop on the Occurrence, Effects and Fate of Microplastic Marine Debris, Sept. 9-11, 2008. NOAA Technical Memorandum NOS-OR\&amp;R-30.

Ayawei, N., Ebelegi, A.N., Wankasi, D., 2017. Modelling and interpretation of adsorption isotherms. J. Chem. https://doi.org/10.1155/2017/3039817.

Bakir, A., Rowland, S.J., Thompson, R.C., 2014. Enhanced desorption of persistent organic pollutants from microplastics under simulated physiological conditions. Environ. Pollut. 185, 16-23. https://doi.org/10.1016/J.ENVPOL.2013.10.007.

Batel, A., Linti, F., Scherer, M., Erdinger, L., Braunbeck, T., 2016. Transfer of benzo[a]pyrene from microplastics to Artemia nauplii and further to zebrafish via a trophic food web experiment: CYP1A induction and visual tracking of persistent organic pollutants. Environ. Toxicol. Chem. 35, 1656-1666. https://doi.org/10.1002/etc.3361.

Belaiche, C., Holt, A., Saada, A., 2009. Nonylphenol ethoxylate plastic additives inhibit mitochondrial respiratory chain complex I. Clin. Chem. 55, 1883-1884. https://doi.org/ 10.1373/CLINCHEM.2009.130054.

Besseling, E., Wegner, A., Foekema, E.M., van den Heuvel-Greve, M.J., Koelmans, A.A., 2013. Effects of microplastic on fitness and PCB bioaccumulation by the lugworm Arenicola marina (L.). Environ. Sci. Technol. 47, 593-600. https://doi.org/10.1021/ es302763x.

Brennecke, D., Duarte, B., Paiva, F., Caçador, I., Canning-Clode, J., 2016. Microplastics as vector for heavy metal contamination from the marine environment. Estuar. Coast Shelf Sci. 178, 189-195. https://doi.org/10.1016/j.ecss.2015.12.003.

Carbery, M., O'Connor, W., Palanisami, T., 2018. Trophic transfer of microplastics and mixed contaminants in the marine food web and implications for human health. Environ. Int. 115, 400-409. https://doi.org/10.1016/J.ENVINT.2018.03.007.

Chen, X., 2015. Modeling of experimental adsorption isotherm data. Inf 6, 14-22. https:// doi.org/10.3390/info6010014.
Chen, Q., Zhang, H., Allgeier, A., Zhou, Q., Ouellet, J.D., 2019. Marine microplastics bound dioxin-like chemicals: model explanation and risk assessment. J. Hazard. Mater. 364, 82-90. https://doi.org/10.1016/j.jhazmat.2018.10.032.

Cheung, L.T.O., Lui, C.Y., Fok, L., 2018. Microplastic contamination of wild and captive flathead grey mullet (Mugil cephalus). Int. J. Environ. Res. Public Health 15, 597. https:// doi.org/10.3390/ijerph15040597.

Cho, Y., Shim, W.J., Jang, M., Han, G.M., Hong, S.H., 2019. Abundance and characteristics of microplastics in market bivalves from South Korea. Environ. Pollut. 245, 1107-1116. https://doi.org/10.1016/J.ENVPOL.2018.11.091.

Chua, E.M., Shimeta, J., Nugegoda, D., Morrison, P.D., Clarke, B.O., 2014. Assimilation of polybrominated diphenyl ethers from microplastics by the marine amphipod allorchestes compressa. Environ. Sci. Technol. 48, 8127-8134. https://doi.org/ 10.1021/es405717z.

Cornelissen, G., Gustafsson, Ö., Bucheli, T.D., Jonker, M.T.O., Koelmans, A.A., Van Noort, P.C.M., 2005. Extensive sorption of organic compounds to black carbon, coal, and kerogen in sediments and soils: mechanisms and consequences for distribution, bioaccumulation, and biodegradation. Environ. Sci. Technol. https://doi.org/10.1021/ es050191b.

Desta, M.B., 2013. Batch sorption experiments: Langmuir and freundlich isotherm studies for the adsorption of textile metal ions onto teff straw (eragrostis tef) agricultural waste. J. Thermodyn. 2013, 6. https://doi.org/10.1155/2013/375830.

Digka, N., Tsangaris, C., Torre, M., Anastasopoulou, A., Zeri, C., 2018. Microplastics in mussels and fish from the Northern Ionian Sea. Mar. Pollut. Bull. 135, 30-40. https://doi. org/10.1016/J.MARPOLBUL.2018.06.063.

Eerkes-Medrano, D., Thompson, R.C., Aldridge, D.C., 2015. Microplastics in freshwater systems: a review of the emerging threats, identification of knowledge gaps and prioritisation of research needs. Water Res. 75, 63-82. https://doi.org/10.1016/j. watres.2015.02.012.

Eichbaum, K., Brinkmann, M., Buchinger, S., Reifferscheid, G., Hecker, M., Giesy, J.P., Engwall, M., van Bavel, B., Hollert, H., 2014. In vitro bioassays for detecting dioxinlike activity - application potentials and limits of detection, a review. Sci. Total Environ. 487, 37-48. https://doi.org/10.1016/J.SCITOTENV.2014.03.057.

Endo, S., Koelmans, A.A., 2016. Sorption of hydrophobic organic compounds in marine environments: Equilibrium. Hazardous Chemicals Associated with Plastics in the Marine Environment, pp. 1-20. https://doi.org/10.1007/698_2016_11.

Endo, S., Takizawa, R., Okuda, K., Takada, H., Chiba, K., Kanehiro, H., Ogi, H., Yamashita, R. Date, T., 2005. Concentration of polychlorinated biphenyls (PCBs) in beached resin pellets: variability among individual particles and regional differences. Mar. Pollut. Bull. 50, 1103-1114. https://doi.org/10.1016/j.marpolbul.2005.04.030.

Endo, S., Yuyama, M., Takada, H., 2013. Desorption kinetics of hydrophobic organic contaminants from marine plastic pellets. Mar. Pollut. Bull. 74, 125-131. https://doi. org/10.1016/J.MARPOLBUL.2013.07.018.

Erni-Cassola, G., Zadjelovic, V., Gibson, M.I., Christie-Oleza, J.A., Distribution of plastic polymer types in the marine environment; A meta-analysis, Journal of Hazardous Materials, 369, 691 - 698. https://doi.org/10.1016/j.jhazmat.2019.02.067

European Centre for Ecotoxicology and Toxicology of Chemicals, 2013. Environmental exposure assessment of ionisable organic compounds. ECETOC Technical Report No 123.

Faure, F., Demars, C., Wieser, O., Kunz, M., de Alencastro, L.F., 2015. Plastic pollution in Swiss surface waters: nature and concentrations, interaction with pollutants. Environ. Chem. 12, 582. https://doi.org/10.1071/EN14218.

Fikarová, K., Cocovi-Solberg, D.J., Rosende, M., Horstkotte, B., Sklenářová, H., Miró M., 2019. A flow-based platform hyphenated to on-line liquid chromatography for automatic leaching tests of chemical additives from microplastics into seawater. J. Chromatogr. A 1602, 160-167. https://doi.org/10.1016/J. CHROMA.2019.06.041.

Fotopoulou, K.N., Karapanagioti, H.K., 2012. Surface properties of beached plastic pellets. Mar. Environ. Res. 81, 70-77. https://doi.org/10.1016/j.marenvres.2012.08.010.

GESAMP Joint Group of Experts on the Scientific Aspects of Marine Environmenta Protection, 2015. Sources, fate and effects of microplastics in the marine environment: a global assessment. Reports Stud. GESAMP 90, 96. https://doi.org/10.13140/ RG.2.1.3803.7925.

Goedecke, C., Mülow-stollin, U., Hering, S., Richter, J., Piechotta, C., Paul, A., Braun, U., 2017. A first pilot study on the sorption of environmental pollutants on various microplastic materials. J. Environ. Anal. Chem. 4, 1-8. https://doi.org/10.4172/23802391.1000191.

Goss, K.-U., Schwarzenbach, R.P., 2003. Rules of thumb for assessing equilibrium partitioning of organic compounds: successes and pitfalls. J. Chem. Educ. 80, 450. https://doi.org/10.1021/ed080p450.

Guo, X., Wang, X., Zhou, X., Kong, X., Tao, S., Xing, B., 2012. Sorption of four hydrophobic organic compounds by three chemically distinct polymers: role of chemical and physical composition. Environ. Sci. Technol. 46, 7252-7259. https://doi.org/10.1021/ es301386z.

Guo, X., Pang, J., Chen, S., Jia, H., 2018. Chemosphere sorption properties of tylosin on four different microplastics. Chemosphere 209, 240-245. https://doi.org/10.1016/j. chemosphere.2018.06.100.

Hartmann, N.B., Rist, S., Bodin, J., Meibom, A., Jensen, L.H., Baun, A., Schmidt, S.N., Mayer, P., 2017. Microplastics as vectors for environmental contaminants: exploring sorption, desorption, and transfer to biota. Integr. Environ. Assess. Manag. 13, 488-493. https://doi.org/10.1002/ieam.1904.

Hermabessiere, L., Dehaut, A., Paul-Pont, I., Lacroix, C., Jezequel, R., Soudant, P., Duflos, G., 2017. Occurrence and effects of plastic additives on marine environments and organisms: a review. Chemosphere 182, 781-793. https://doi.org/10.1016/J. CHEMOSPHERE.2017.05.096.

Ho, Y.S., Ng, J.C.Y., McKay, G., 2000. Kinetics of pollutant sorption by biosorbents: review. Sep. Purif. Methods 29, 189-232. https://doi.org/10.1081/SPM-100100009. 
Hüffer, T., Hofmann, T., 2016. Sorption of non-polar organic compounds by micro-sized plastic particles in aqueous solution. Environ. Pollut. 214, 194-201. https://doi.org/ 10.1016/j.envpol.2016.04.018.

Hüffer, T., Weniger, A.-K., Hofmann, T., 2018. Sorption of organic compounds by aged polystyrene microplastic particles. Environ. Pollut. 236, 218-225. https://doi.org/ 10.1016/J.ENVPOL.2018.01.022.

Jambeck, J.R., Geyer, R., Wilcox, C., Siegler, T.R., Perryman, M., ... Andrady, A.Law, 2015. Plastic waste inputs from land into the ocean. Science 347 (6223), 768-771. https://doi.org/10.1126/science.1260352.

Jang, M., Shim, W.J., Han, G.M., Rani, M., Song, Y.K., Hong, S.H., 2017. Widespread detection of a brominated flame retardant, hexabromocyclododecane, in expanded polystyrene marine debris and microplastics from South Korea and the Asia-Pacific coastal region. Environ. Pollut. 231, 785-794. https://doi.org/10.1016/j. envpol.2017.08.066.

Joshi, G., Naithani, S., Varshney, V.K., Bisht, S.S., Rana, V., 2017. Potential use of waste paper for the synthesis of cyanoethyl cellulose: a cleaner production approach towards sustainable environment management. J. Clean. Prod. 142, 3759-3768. https://doi.org/10.1016/j.jclepro.2016.10.089.

Karami, A., Golieskardi, A., Choo, C.K., Larat, V., Karbalaei, S., Salamatinia, B., 2018 Microplastic and mesoplastic contamination in canned sardines and sprats. Sci. Total Environ. 612, 1380-1386. https://doi.org/10.1016/j.scitotenv.2017.09.005.

Kelly, B.C., Ikonomou, M.G., Blair, J.D., Morin, A.E., Gobas, F.A.P.C., 2007. Food web-specific biomagnification of persistent organic pollutants. Science (80-.) 317, 236-239. https://doi.org/10.1126/science.1138275.

Koelmans, A.A., Bakir, A., Burton, G.A., Janssen, C.R., 2016. Microplastic as a vector for chemicals in the aquatic environment: critical review and model-supported reinterpretation of empirical studies. Environ. Sci. Technol. https://doi.org/10.1021/acs. est.5b06069.

Krüger, O., Kalbe, U., Meißner, K., Sobottka, S., 2014. Sorption effects interfering with the analysis of polycyclic aromatic hydrocarbons $(\mathrm{PAH})$ in aqueous samples. Talanta 122 151-156. https://doi.org/10.1016/j.talanta.2014.01.038.

Lee, H., Shim, W.J., Kwon, J.H., 2014. Sorption capacity of plastic debris for hydrophobic organic chemicals. Sci. Total Environ. 470-471, 1545-1552. https://doi.org/10.1016/j. scitotenv.2013.08.023.

León, V.M., García-Agüera, I., Moltó, V., Fernández-González, V., Llorca-Pérez, L., Andrade J.M., Muniategui-Lorenzo, S., Campillo, J.A., 2019. PAHs, pesticides, personal care products and plastic additives in plastic debris from Spanish Mediterranean beaches. Sci. Total Environ. 670, 672-684. https://doi.org/10.1016/J.SCITOTENV.2019.03.216.

Li, J., Zhang, K., Zhang, H., 2018. Adsorption of antibiotics on microplastics. Environ. Pollut. 237, 460-467. https://doi.org/10.1016/J.ENVPOL.2018.02.050.

Liebezeit, G., Liebezeit, E., 2013. Non-pollen particulates in honey and sugar. Food Addit. Contam. - Part A Chem. Anal. Control. Expo. Risk Assess. 30, 2136-2140. https://doi. org/10.1080/19440049.2013.843025.

Liebezeit, G., Liebezeit, E., 2014. Synthetic particles as contaminants in German beers. Food Addit. Contam. - Part A Chem. Anal. Control. Expo. Risk Assess. 31 1574-1578. https://doi.org/10.1080/19440049.2014.945099.

Lithner, D., Larsson, Å., Dave, G., 2011. Environmental and health hazard ranking and assessment of plastic polymers based on chemical composition. Sci. Total Environ. 409, 3309-3324. https://doi.org/10.1016/J.SCITOTENV.2011.04.038.

Liu, F., Liu, G., Zhu, Z., Wang, S., Zhao, F., 2019a. Interactions between microplastics and phthalate esters as affected by microplastics characteristics and solution chemistry. Chemosphere 214, 688-694. https://doi.org/10.1016/j. chemosphere.2018.09.174.

Liu, G., Zhu, Z., Yang, Y., Sun, Y., Yu, F., Ma, J., 2019b. Sorption behavior and mechanism of hydrophilic organic chemicals to virgin and aged microplastics in freshwater and seawater. Environ. Pollut. 246, 26-33. https://doi.org/10.1016/j.envpol.2018.11.100.

Loyo-Rosales, J.E., Rosales-Rivera, G.C., Lynch, A.M., Rice, C.P., Torrents, A., 2004. Migration of Nonylphenol from Plastic Containers to Water and a Milk Surrogate. https://doi. org/10.1021/JF0345696.

Luo, H., Xiang, Y., He, D., Li, Y., Zhao, Y., Wang, S., Pan, X., 2019. Leaching behavior of fluorescent additives from microplastics and the toxicity of leachate to Chlorella vulgaris. Sci. Total Environ. 678, 1-9. https://doi.org/10.1016/J.SCITOTENV.2019.04.401.

MacKay, A.A., Canterbury, B., 2005. Oxytetracycline sorption to organic matter by metalbridging. J. Environ. Qual. 34, 1964. https://doi.org/10.2134/jeq2005.0014.

Marcato, B., Guerra, S., Vianello, M., Scalia, S., 2003. Migration of antioxidant additives from various polyolefinic plastics into oleaginous vehicles. Int. J. Pharm. 257, 217-225. https://doi.org/10.1016/S0378-5173(03)00143-1.

Marion, G.M., Millero, F.J., Camões, M.F., Spitzer, P., Feistel, R., Chen, C.-T.A., 2011. pH of seawater. Mar. Chem. 126, 89-96. https://doi.org/10.1016/J.MARCHEM.2011.04.002

Martins, A.C., Pezoti, O., Cazetta, A.L., Bedin, K.C., Yamazaki, D.A.S., Bandoch, G.F.G. Asefa, T., Visentainer, J.V., Almeida, V.C., 2015. Removal of tetracycline by $\mathrm{NaOH}$-activated carbon produced from macadamia nut shells: Kinetic and equilibrium studies. Chem. Eng. J. 260, 291-299. https://doi.org/10.1016/J CEJ.2014.09.017

Mato, Y., Isobe, T., Takada, H., Kanehiro, H., Ohtake, C., Kaminuma, T., 2001. Plastic resin pellets as a transport medium for toxic chemicals in the marine environment. Environ. Sci. Technol. 35, 318-324. https://doi.org/10.1021/es0010498.

Mato, Y., Takada, H., Zakaria, M.P., 2002. Toxic chemicals contained in plastic resin pellets in the marine environment - spatial difference in pollutant concentrations and the ef fects of resin type. Kankyo Kagakukaishi 15, 415-423. https://doi.org/10.11353/ sesj1988.15.415.

Mayer, Z.A., Eltom, Y., Stennett, D., Schröder, E., Apfelbacher, A., Hornung, A., 2014. Characterization of engineered biochar for soil management. Environ. Prog. Sustain. Energy 33, 490-496. https://doi.org/10.1002/ep.11788.

Miranda, D. de A., de Carvalho-Souza, G.F., 2016. Are we eating plastic-ingesting fish? Mar. Pollut. Bull. 103, 109-114. https://doi.org/10.1016/j.marpolbul.2015.12.035.
Miyake, Y., Ishida, H., Tanaka, S., Kolev, S.D., 2013. Theoretical analysis of the pseudosecond order kinetic model of adsorption. Application to the adsorption of $\mathrm{Ag}(\mathrm{I})$ to mesoporous silica microspheres functionalized with thiol groups. Chem. Eng. J. 218, 350-357. https://doi.org/10.1016/J.CEJ.2012.11.089.

Murphy, F., Russell, M., Ewins, C., Quinn, B., 2017. The uptake of macroplastic \& microplastic by demersal \& pelagic fish in the Northeast Atlantic around Scotland. Mar. Pollut. Bull. 122, 353-359. https://doi.org/10.1016/j.marpolbul.2017.06.073.

Napper, I.E., Thompson, R.C., 2019. Environmental Deterioration of Biodegradable, Oxobiodegradable, Compostable, and Conventional Plastic Carrier Bags in the Sea, Soil, and Open-Air Over a 3-Year Period. Environ. Sci. Technol. 53, 4775-4783. https:// doi.org/10.1021/acs.est.8b06984.

Nelms, S.E., Galloway, T.S., Godley, B.J., Jarvis, D.S., Lindeque, P.K., 2018. Investigating microplastic trophic transfer in marine top predators. Environ. Pollut. 238, 999-1007. https://doi.org/10.1016/J.ENVPOL.2018.02.016.

Net, S., Sempéré, R., Delmont, A., Paluselli, A., Ouddane, B., 2015. Occurrence, fate, behavior and ecotoxicological state of phthalates in different environmental matrices. Environ. Sci. Technol. 49, 4019-4035. https://doi.org/10.1021/es505233b.

Neves, D., Sobral, P., Ferreira, J.L., Pereira, T., 2015. Ingestion of microplastics by commercial fish off the Portuguese coast. Mar. Pollut. Bull. 101, 119-126. https://doi.org/ 10.1016/J.MARPOLBUL.2015.11.008.

Nguyen, T.N., Goss, K.-U., Ball, W.P., 2005. Polyparameter Linear Free Energy Relationships for Estimating the Equilibrium Partition of Organic Compounds between Water and the Natural Organic Matter in Soils and Sediments. https://doi.org/10.1021/ ES048839S.

NOAA, 2018. What are microplastics?. [WWW Document]. URL. Natl. Ocean. Atmos. Admhttps://oceanservice.noaa.gov/facts/microplastics.html (accessed 9.26.19)

O'Connor, I.A., Golsteijn, L., Hendriks, A.J., 2016. Review of the partitioning of chemicals into different plastics: consequences for the risk assessment of marine plastic debris. Mar. Pollut. Bull. https://doi.org/10.1016/j.marpolbul.2016.07.021.

Peixoto, D., Pinheiro, C., Amorim, J., Oliva-Teles, L., Guilhermino, L., Vieira, M.N., 2019. Microplastic pollution in commercial salt for human consumption: a review. Estuar. Coast. Shelf Sci. 219, 161-168. https://doi.org/10.1016/J.ECSS.2019.02.018.

Pérez-Lobato, R., Mustieles, V., Calvente, I., Jiménez-Díaz, I., Ramos, R., Caballero- Casero, N., López-Jiménez, F.J., Rubio, S., Olea, N., Fernández, M.F., 2016. Exposure to Bisphenol A and behavior in school-age children. NeuroToxicology 53, 12-19.

Perkinelmer, 2019. Melting point, glass transition temperature and structure of common polymers. [WWW Document]. URL. https://www.perkinelmer.com/CMSResources/ Images/44-74863TCH_MPTGAndStructureOfCommonPolymers.pdf (accessed 5.30.19)

Ramirez, M.M.B., Caamal, R.D., von Osten, J.R., 2019. Occurrence and seasonal distribution of microplastics and phthalates in sediments from the urban channel of the Ria and coast of Campeche, Mexico. Sci. Total Environ. 672, 97-105. https://doi.org/ 10.1016/j.scitotenv.2019.03.472.

Rani, M., Shim, W.J., Han, G.M., Jang, M., Al-Odaini, N.A., Song, Y.K., Hong, S.H., 2015. Qualitative analysis of additives in plastic marine debris and its new products. Arch. Environ. Contam. Toxicol. 69, 352-366. https://doi.org/10.1007/s00244-015-0224-x.

Razanajatovo, R.M., Ding, J., Zhang, S., Jiang, H., Zou, H., 2018. Sorption and desorption of selected pharmaceuticals by polyethylene microplastics. Mar. Pollut. Bull. 136, 516-523. https://doi.org/10.1016/j.marpolbul.2018.09.048.

Reinas, I., Oliveira, J., Pereira, J., Machado, F., Poças, M.F., 2012. Migration of two antioxidants from packaging into a solid food and into Tenax®. Food Control 28, 333-337. https://doi.org/10.1016/J.FOODCONT.2012.05.023.

Rios Mendoza, L.M., Jones, P.R., 2015. Characterisation of microplastics and toxic chemicals extracted from microplastic samples from the North Pacific Gyre. Environ. Chem. 12, 611-617. https://doi.org/10.1071/EN14236.

Rist, S., Carney Almroth, B., Hartmann, N.B., Karlsson, T.M., 2018. A critical perspective on early communications concerning human health aspects of microplastics. Sci. Total Environ. 626, 720-726. https://doi.org/10.1016/J.SCITOTENV.2018.01.092.

Rivas, B.L., et al., 2018. Water-soluble and insoluble polymers, nanoparticles, nanocomposites and hybrids with ability to remove hazardous inorganic pollutants in water. Frontiers in Chemistry 6, 320.

Rochman, C.M., 2013. Plastics and priority pollutants: a multiple stressor in aquatic habitats. Environ. Sci. Technol. 2439-2440.

Rochman, C.M., 2015. The Complex Mixture, Fate and Toxicity of Chemicals Associated with Plastic Debris in the Marine Environment. , pp. 117-140. https://doi.org/ 10.1007/978-3-319-16510-3_5.

Rochman, C.M., Hoh, E., Kurobe, T., Teh, S.J., 2013a. Ingested plastic transfers hazardous chemicals to fish and induces hepatic stress. Sci. Rep. 3, 3263. https://doi.org/ 10.1038/srep03263.

Rochman, C.M., Manzano, C., Hentschel, B.T., Simonich, S.L.M., Hoh, E., 2013b. Polystyrene plastic: a source and sink for polycyclic aromatic hydrocarbons in the marine environment. Environ. Sci. Technol. 47, 13976-13984. https://doi.org/10.1021/es403605f.

Rochman, C.M., Lewison, R.L., Eriksen, M., Allen, H., Cook, A.M., Teh, S.J., 2014. Polybrominated diphenyl ethers (PBDEs) in fish tissue may be an indicator of plastic contamination in marine habitats. Sci. Total Environ. 476-477, 622-633. https://doi. org/10.1016/j.scitotenv.2014.01.058.

Rowdhwal, S.S.S., Chen, J., 2018. Toxic effects of di-2-ethylhexyl phthalate: an overview. Biomed. Res. Int. 2018, 1-10. https://doi.org/10.1155/2018/1750368.

Scopetani, C. Cincinelli, A., Martellini, T., Lombardini, E., Ciofini, A., Fortunati, A., Pasquali, V., Ciattini, S., Ugolini, A., 2018. Ingested microplastic as a two-way transporter for PBDEs in Talitrus saltator. Environ. Res. 167, 411-417. https://doi.org/10.1016/J. ENVRES.2018.07.030.

Seidensticker, S., Grathwohl, P., Lamprecht, J., Zarfl, C., 2018. A combined experimental and modeling study to evaluate $\mathrm{pH}$ - dependent sorption of polar and non - polar compounds to polyethylene and polystyrene microplastics. Environ. Sci. Eur. 30, 1-12. https://doi.org/10.1186/s12302-018-0155-z. 
Skrip, S., Das, G.K., Chatterjee, S.G., 2013. Analytical expressions for the adsorbate breakthrough curve from a fixed bed of adsorbent with first-order and second-order kinetic models. Indian Chem. Eng. 55, 87-103. https://doi.org/10.1080/ 00194506.2013 .798490$.

Stenzel, A., Goss, K.-U., Endo, S., 2013. Determination of polyparameter linear free energy relationship (pp-LFER) substance descriptors for established and alternative flame retardants. Environ. Sci. Technol., 130125075250002 https://doi.org/10.1021/ es304780a.

Stringer, R., Johnston, P., 2001. Chlorine and the environment. Igarss 2014. https://doi.org/ 10.1007/978-94-015-9813-2.

Sun, X., Liang, J., Zhu, M., Zhao, Y., Zhang, B., 2018. Microplastics in seawater and zooplankton from the Yellow Sea. Environ. Pollut. 242, 585-595. https://doi.org/ 10.1016/J.ENVPOL.2018.07.014.

Sundt, P., Schulze, P., Syversen, F., 2014. Sources of Microplastic-Pollution to the Marine Environment Project Report.

Teuten, E.L., Rowland, S.J., Galloway, T.S., Thompson, R.C., 2007. Potential for plastics to transport hydrophobic contaminants. Environ. Sci. Technol. 41, 7759-7764. https:// doi.org/10.1021/es071737s.

Teuten, E.L., Saquing, J.M., Knappe, D.R.U., Barlaz, M.A., Jonsson, S., Björn, A., Rowland, S.J., Thompson, R.C., Galloway, T.S., Yamashita, R., Ochi, D., Watanuki, Y., Moore, C., Viet, P.H., Tana, T.S., Prudente, M., Boonyatumanond, R., Zakaria, M.P., Akkhavong, K., Ogata, Y., Hirai, H., Iwasa, S., Mizukawa, K., Hagino, Y., Imamura, A., Saha, M., Takada, H., 2009. Transport and release of chemicals from plastics to the environment and to wildlife. Philos. Trans. R. Soc. B 364, 2027-2045. https://doi.org/10.1098/ rstb.2008.0284.

Thompson, R., 2016. Sources, fate and effects of microplastics in the marine environment (2012-2018). Insights from the GESAMP Report(S) on Microplastics.

Uber, T.H., Hüffer, T., Planitz, S., Schmidt, T.C., 2019. Characterization of sorption properties of high-density polyethylene using the poly-parameter linearfree-energy relationships. Environ. Pollut. 248, 312-319. https://doi.org/10.1016/J. ENVPOL.2019.02.024.

USEPA, 2010. Nonylphenol (NP) and nonylphenol ethoxylates (NPEs). WWW Document. URL. United States Environ. Prot. Agencyhttps://www.epa.gov/sites/production/files/ 2015-09/documents/rin2070-za09_np-npes_action_plan_final_2010-08-09.pdf (accessed 10.1.19).

USEPA, 2017. Technical fact sheet - Polybrominated Diphenyl ethers (PBDEs). U.S. EPA Fed. Facil. Restor. Reuse off, pp. 1-5.

Van Cauwenberghe, L., Claessens, M., Vandegehuchte, M.B., Janssen, C.R., 2015. Microplastics are taken up by mussels (Mytilus edulis) and lugworms (Arenicola marina) living in natural habitats. Environ. Pollut. 199, 10-17. https://doi.org/10.1016/J. ENVPOL.2015.01.008.

Velzeboer, I., Kwadijk, C.J.A.F., Koelmans, A.A., 2014. Strong sorption of PCBs to nanoplastics, microplastics, carbon nanotubes, and fullerenes. Environ. Sci. Technol. 48, 4869-4876. https://doi.org/10.1021/es405721v.

Vethaak, A.D., Leslie, H.A., 2016. Plastic debris is a human health issue. Environ. Sci. Technol. 50, 6825-6826. https://doi.org/10.1021/acs.est.6b02569.

vlab.amrita.edu, 2011. Asorption isotherm. WWW Document. URL. Virtual Amrita Labotratories Univers. Educhttp://vlab.amrita.edu/?sub=2\&brch=190\&sim= $606 \& \mathrm{cnt}=1$.

Voparil, I.M., Mayer, L.M., 2000. Dissolution of sedimentary polycyclic aromatic hydrocarbons into the lugworm's (Arenicola marina) digestive fluids. Environ. Sci. Technol. 34, 1221-1228. https://doi.org/10.1021/es990885i.

Wang, W., Wang, J., 2018a. Different partition of polycyclic aromatic hydrocarbon on environmental particulates in freshwater: microplastics in comparison to natural sediment. Ecotoxicol. Environ. Saf. 147, 648-655. https://doi.org/10.1016/J. ECOENV.2017.09.029.

Wang. W., Wang. J., 2018b. Ecotoxicology and environmental safety different partition of polycyclic aromatic hydrocarbon on environmental particulates in freshwater: microplastics in comparison to natural sediment. Ecotoxicol. Environ. Saf. 147, 648-655. https://doi.org/10.1016/j.ecoenv.2017.09.029.

Wang, Y., Hu, Y., Zhao, X., Wang, S., Xing, G., 2013. Comparisons of biochar properties from wood material and crop residues at different temperatures and residence times. Energy Fuel 27, 5890-5899. https://doi.org/10.1021/ef400972z.

Wang, R., Tang, J., Xie, Z., Mi, W., Chen, Y., Wolschke, H., et al., 2015. Occurrence and spatial distribution of organophosphate ester flame retardants and plasticizers in 40 rivers draining into the Bohai Sea, north China. Environ. Pollut. 198, 172-178.

Wang, Z., Chen, M., Zhang, L., Wang, K., Yu, X., Zheng, Z., Zheng, R., 2018. Sorption behaviors of phenanthrene on the microplastics identi fi ed in a mariculture farm in Xiangshan Bay, southeastern China. Sci. Total Environ. 628-629, 1617-1626. https://doi.org/10.1016/j.scitotenv.2018.02.146.

Weber, W.J., Morris, J.C., 1962. Advances in water pollution research: removal of biologically resistant pollutant from waste water by adsorption. International Conference on Water Pollution Symposium 2. Pergamon, Oxford, pp. 231-266.

Westerdahl, J., Belhaj, M., Rydberg, T., Munthe, J., Darbra, R.M., Alba, À., Heise, S., Ziyang, L. 2012. Additives and other hazardous compounds in electronic products and their waste. The Handbook of Environmental Chemistry 18: Global Risk-Based Management of Chemical Additives I: Production, Usage and Environmental Occurrence, pp. 57-81. https://doi.org/10.1007/698_2011_114.

Wu, P., Cai, Z., Jin, H., Tang, Y., 2019. Adsorption mechanisms of five bisphenol analogues on PVC microplastics. Sci. Total Environ. 650, 671-678. https://doi.org/10.1016/J SCITOTENV.2018.09.049.

Xiao, Y., Xue, Y., Gao, F., Mosa, A., 2017. Sorption of heavy metal ions onto crayfish shell biochar: effect of pyrolysis temperature, $\mathrm{pH}$ and ionic strength. J. Taiwan Inst. Chem. Eng. 80, 114-121. https://doi.org/10.1016/J.JTCE.2017.08.035.

$\mathrm{Xu}, \mathrm{B} ., \mathrm{Liu}, \mathrm{F} ., \mathrm{Brookes}$, P.C., Xu, J., 2018. The sorption kinetics and isotherms of sulfamethoxazole with polyethylene microplastics. Mar. Pollut. Bull. 131, 191-196. https://doi org/10.1016/j.marpolbul.2018.04.027.

Xu, P., Ge, W., Chai, C., Zhang, Y., Jiang, T., Xia, B., 2019. Sorption of polybrominated diphenyl ethers by microplastics. Mar. Pollut. Bull. 145, 260-269. https://doi.org/ 10.1016/J.MARPOLBUL.2019.05.050.

Yang, D., Shi, H., Li, L., Li, J., Jabeen, K., Kolandhasamy, P., 2015. Microplastic pollution in table salts from China. Environ. Sci. Technol. 49, 13622-13627. https://doi.org/ 10.1021/acs.est.5b03163.

Zarfl, C., Fleet, D., Fries, E., Galgani, F., Gerdts, G., Hanke, G., Matthies, M., 2011 Microplastics in oceans. Mar. Pollut. Bull. 62, 1589-1591. https://doi.org/10.1016/j. marpolbul.2011.02.040.

Zhan, Z., Wang, J., Peng, J., Xie, Q., Huang, Y., Gao, Y., 2016. Sorption of 3,3',4,4' tetrachlorobiphenyl by microplastics: a case study of polypropylene. Msrine Polution Bull 110, 559-563. https://doi.org/10.1016/j.marpolbul.2016.05.036.

Zhang, H., Wang, J., Zhou, B., Zhou, Y., Dai, Z., Zhou, Q., Chriestie, P., Luo, Y., 2018a. Enhanced adsorption of oxytetracycline to weathered microplastic polystyrene: kinetics, isotherms and in fl uencing factors*. Environ. Pollut. 243, 1550-1557. https:// doi.org/10.1016/j.envpol.2018.09.122.

Zhang, H., Zhou, Q., Xie, Z., Zhou, Y., Tu, C., Fu, C., Mi, W., Ebinghaus, R., Christie, P., Luo, Y. 2018b. Occurrences of organophosphorus esters and phthalates in the microplastics from the coastal beaches in north China. Sci. Total Environ. 616-617, 1505-1512. https://doi.org/10.1016/j.scitotenv.2017.10.163.

Zhang X. Zheng M. Yin, X., Wang, L., Lou, Y., Qu, L., Liu, X, Zhu, H., Qiu, Y, 2019. Sorption of 3,6-dibromocarbazole and 1,3,6,8-tetrabromocarbazole by microplastics. Mar. Pollut. Bull. 138, 458-463. https://doi.org/10.1016/j.marpolbul.2018.11.055.

Zuo, L., Li, H., Lin, L., Sun, Y., Diao, Z., Liu, S., Zhang, Z., Xu, X., 2019. Sorption and desorption of phenanthrene on biodegradable poly (butylene adipate co-terephtalate) microplastics. Chemosphere 215, 25-32. https://doi.org/10.1016/j. chemosphere.2018.09.173. 